Check for updates

Cite this: RSC Adv., 2017, 7, 33344

\title{
Efficient Ugi reactions in an aqueous vesicle system $\dagger$
}

\author{
Arleta Madej, ${ }^{a}$ Daniel Paprocki, ${ }^{a}$ Dominik Koszelewski, ${ }^{a}$ Anna Żądło-Dobrowolska, ${ }^{a}$ \\ Anna Brzozowska, (D) ${ }^{b}$ Peter Walde (D) ${ }^{c}$ and Ryszard Ostaszewski (iD *a
}

A new, alternative route for the synthesis of a variety of $\alpha$-aminoacyl amides via the four-component Ugi reaction in the presence of different types of surfactants was investigated. The best results were obtained if the reaction was carried out in the presence of either didodecyldimethylammonium bromide (DDAB) vesicles or Triton X-100 micelles. The presence of vesicles or micelles in these systems was confirmed by applying dynamic light scattering (DLS) and fluorescence measurements. Additionally, detailed studies of the dependence on the concentration of the two surfactants and on their reusability were performed. The obtained results demonstrate the beneficial effect aqueous surfactant systems may have on the course of the Ugi-multicomponent reaction.

Received 22nd March 2017

Accepted 7th June 2017

DOI: $10.1039 / \mathrm{c} 7 \mathrm{ra03376a}$

rsc.li/rsc-advances

(DODAB), didodecyldimethylammonium bromide (DDAB). ${ }^{5}$

\section{Introduction}

Traditionally, and at least until the end of the 20th century, water was not the first choice as reaction medium for synthetic organic chemical transformations. ${ }^{1}$ However, in recent years, organic chemistry in water has received much attention. ${ }^{2}$ This is justified by the fact that water exhibits unique reactivity and selectivity but also it is an economical and environmentally friendly solvent. ${ }^{3}$

One major inconvenience of the usage of water is the fact that most organic compounds are insoluble or almost insoluble in aqueous solutions. This limitation can be overcome by applying surfactants (amphiphiles), which often increase the solubility of organic compounds due to the formation of aggregates (e.g. micelles or vesicles). The presence of surfactants may also increase reaction rates, which can be explained by a few effects: enhanced concentration of the reacting species in the area of the aggregates, a different polarity of the actual locus where the reaction takes place and also possible steric hindrance so that the extent of side reactions is decreased. ${ }^{4}$

Recently, there has been an increasing interest in artificial vesicles which can be formed under specific conditions in water solution from certain amphiphiles, e.g. from 1-palmitoyl-2-oleoyl$s n$-glycero-3-phosphocholine (POPC), sodium bis(2-ethylhexyl) sulfosuccinate (AOT), dioctadecyldimethylammonium bromide

${ }^{a}$ Institute of Organic Chemistry, Polish Academy of Sciences, Kasprzaka 44/52, 01-224 Warsaw, Poland. E-mail: ryszard.ostaszewski@icho.edu.pl

${ }^{b}$ Institute of Physical Chemistry, Polish Academy of Sciences, Kasprzaka 44/52, 01-224 Warsaw, Poland

${ }^{c}$ Laboratory of Polymer Chemistry, Department of Materials, ETH Zurich, VladimirPrelog-Weg 5, 8093 Zurich, Switzerland

$\dagger$ Electronic supplementary information (ESI) available. See DOI: 10.1039/c7ra03376a
Vesicles have an aqueous interior volume, separated from the bulk aqueous medium by one or several self-closed membranous layers. The formation of vesicles is a two-step self-assembly processes. At the beginning the amphiphile forms a bilayer, which afterwards closes to form a vesicle. ${ }^{6}$ There is a great interest in vesicles because of their wide applications in biology and medicine as model cell membrane systems, as well as their strong potential as drug carriers and for encapsulating other agents of industrial relevance. ${ }^{7}$ In the case of drug delivery systems, vesicles offer unique possibilities of hosting hydrophilic as well as lipophilic drugs. ${ }^{8}$

There is no doubt that for environmental reasons the usage of organic solvents in chemical production should be minimized as good as possible. Therefore, replacing an organic solvent by an aqueous surfactant systems is a valuable approach in synthetic organic chemistry. ${ }^{9}$ During the last years, a lot of organic compounds were obtained by using diverse synthetic transformations in water-surfactant systems, e.g., the thiolysis of $p$ nitrophenyl acetate, the decarboxylation of 6-nitrobenzisoxazole3-carboxylate, ${ }^{10}$ an aza-Diels-Alder reaction, ${ }^{11}$ or an $O$ sulfonylation/Knoevenagel condensation/hetero-Diels-Alder reaction cascade. ${ }^{12}$ Furthermore, Bruce Lipshutz's group performed a great number of various metal catalysed reactions in the presence of surfactant aggregates such as the Suzuki reaction, ${ }^{13}$ the Sonogashira coupling reaction, ${ }^{14}$ trifluoromethylation ${ }^{15}$ or the Pd-catalysed dehalogenation of aryl halides. ${ }^{16}$ Also multicomponent reactions (MCRs) like the Mannich reaction, ${ }^{17}$ the Kinugasa reaction, ${ }^{18}$ the Betti bases synthesis, ${ }^{19}$ or the Passerini reaction, ${ }^{20}$ can be carried out efficiently in aqueous media in the presence of surfactants. Therefore, green, environmentally friendly approaches in organic chemistry are attracting an ever-growing crowd of synthetic chemists. ${ }^{21}$ The growing interests in MCRs is 
based on the increasing number of applications which are notified in medicinal chemistry, drug discovery programs, combinational chemistry, natural product synthesis, argochemistry and polymer chemistry. ${ }^{22}$

One of the most important multicomponent reaction between carboxylic acids, amines, carbonyl compounds (aldehydes or ketones) and isocyanides, described in 1959 by Ugi and later given his name, provides $\alpha$-aminoacyl amides in a one pot four-component reaction (U-4CR). It has substantial potential in molecule creation and it is widely applied in combinatorial chemistry. ${ }^{23}$ For example, U-4CR was explored by process chemists at Merck as a potential route to the blockbuster antiHIV drug Crixivan. ${ }^{24}$

The U-4CR is a reaction which first involves the formation of an imine, followed by the $\alpha$-addition of an isocyanide and finally the Mumm rearrangement. In general, this non-catalyzed reaction has a high atom economy because only one molecule of water is lost from the starting materials during the reaction. ${ }^{25}$ The U-4CR is usually performed in polar protic solvents (like methanol, ethanol, or trifluoroethanol), ${ }^{26}$ also occasionally in polar aprotic solvents like DMF, dichloromethane, chloroform, THF or dioxane. ${ }^{27}$ Unfortunately all mentioned organic solvents are flammable, volatile and harmful. Pirrung and Das Sarma were the first to show that the Passerini three-component reaction (P$3 \mathrm{CR}$ ) and the U-4CR can be performed with very good performance in water. ${ }^{28}$ Recently, we showed that surfactant/water systems provide indeed excellent results for the $\mathrm{P}-3 \mathrm{CR} .^{20}$ Whereas, Mirono et al. reported an example of a U-4CR which proceeded in aqueous solution and showed that the addition of the surfactant cetylpyridinium chloride enhanced the solubility of the reactants, providing a series of five-membered $\beta$-lactam derivatives with higher yields than in surfactant-free water. ${ }^{29}$ However, these studies were conducted only for one type of surfactant, and there was no demonstration of the interdependence between the type of the surfactant and the reaction rate.

The goal of the present paper is the development of an alternative method to access peptide-like structures by the U4CR. Herein, we verified the influence of different aqueous surfactant systems on the Ugi reaction in comparison to commonly used organic solvents. Moreover, under optimized reaction conditions we examined the effect of repeated application of the surfactants and also critically discuss the limitation of the elaborated reaction conditions.

\section{Results and discussion}

For the first set of experiments, we have chosen as model reaction of the U-4CR the reaction of phenylacetic acid (1a), isovaleraldehyde (2a), $p$-methoxybenzylamine (3a) and $p$-methoxybenzyl isocyanide (4a). First, we examined the influence of different solvents on the reaction yield. The results are presented in Table 1. Methanol which is a polar protic solvent was the best among the tested solvents, providing product 5a with 55\% yield (entry 1). This is in good agreement with literature data. ${ }^{26}$ However, in contrast to methanol, usage of ethanol provided product 5a with poor yield (15\%; entry 2 ). Reactions carried out in acetonitrile, ethyl acetate, DCM (dichloromethane) and TBME
Table 1 Solvent influence on the model Ugi reaction ${ }^{a}$

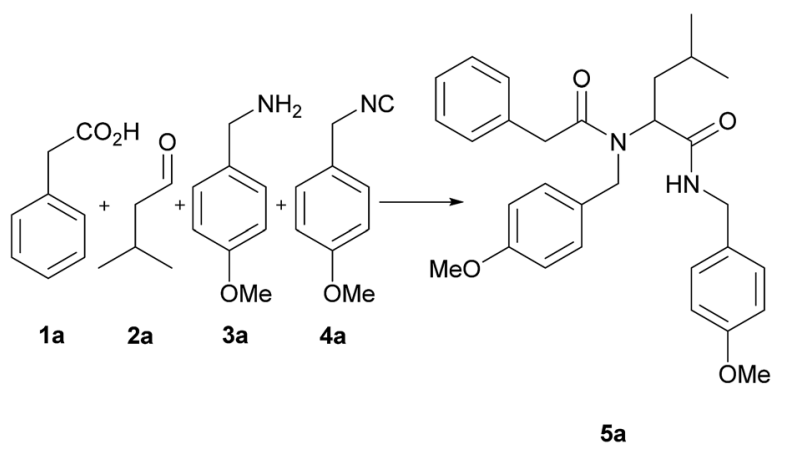

\begin{tabular}{|c|c|c|}
\hline Entry & Solvents & Yield $^{b}(\%)$ \\
\hline 1 & Methanol & 55 \\
\hline 2 & Ethanol & 15 \\
\hline 3 & Acetonitrile & 51 \\
\hline 4 & $\mathrm{DMF}$ & 13 \\
\hline 5 & DCM & 49 \\
\hline 6 & TBME & 47 \\
\hline 7 & Ethyl acetate & 40 \\
\hline 8 & Distilled water & 27 \\
\hline 9 & PBS (pH 7.4) & 19 \\
\hline $\begin{array}{l}{ }^{a} \text { Reaction conditions: } \\
\text { isovaleraldehyde ( } 2 \mathrm{a}, 0.5 \\
\text { methoxybenzyl isocyanid } \\
\text { room temperature. }{ }^{b} \text { Isola }\end{array}$ & $\begin{array}{l}p \text {-methoxyben } z \\
\text { mmol), phenyl } \\
\text { e }(\mathbf{4 a}, 0.5 \text { mmol } \\
\text { ated yields of } 5 \mathbf{a}\end{array}$ & $\begin{array}{l}5 \mathrm{mmol}) \text {, } \\
\mathrm{mmol}), p^{-} \\
\text {for } 48 \mathrm{~h} \text { at }\end{array}$ \\
\hline
\end{tabular}

( $t$-butylmethylether) provided the appropriate products with good yields (up to $51 \%$; entries $3,5,6,7$ ). Application of aqueous phosphate buffer $(\mathrm{pH}=7.4)$ or DMF $(N, N$-dimethylformamide) gave product 5a with poor yields (13-19\%; entries 4, 9). Whereas, in distilled water the product was obtained with almost half the yield in methanol ( $27 \%$; entry 8$)$.

In a next set of experiments, we investigated the influence of different additives on the model Ugi reaction, using 1a, 2a, 3a, and $4 \mathbf{a}$ as reactants in water. Due to the low water solubility of the aldehyde (2a) and the isocyanide (4a), we particularly wondered whether the addition of micelle- or vesicle-forming surfactants lead to an increase in $\mathbf{5 a}$ yield. The additives (including the inorganic salts $\mathrm{NaCl}$ or $\mathrm{CaCl}_{2}$ ) were added at 20 mol\% with respect to the amount of each reactant. The results are presented in Table 2 . They show the following.

In the presence of inorganic salts (entries 2-3), product 5a was obtained with a comparable yield to that without additive. This proves a negligible influence of these additives. Addition of the non-ionic surfactant, Span 60 results in product 5a with poor yield $(20 \%)$, substantially lower than in water alone. However, in the presence of the other non-ionic surfactants tested, Tween 80 , Triton X-100 or TPGS-750-M, the reaction yields were significantly higher (59-60\%; entries 7-9). In the case of anionic (entries $4+5$ ) and zwitterionic surfactants (entry 13), product 5a was obtained with $33-40 \%$ yield. In the presence of cationic surfactants (entries 10-12) the reaction yields were also higher than in water (38-62\%). DDAB turned out to be the 
Table 2 Effect of different additives on the model Ugi reaction in distilled water $^{a}$

\begin{tabular}{lll}
\hline Entry & Additive & Yield $^{b}(\%)$ \\
\hline 1 & - & 27 \\
2 & $\mathrm{NaCl}$ & 27 \\
3 & $\mathrm{CaCl}_{2}$ & 24 \\
4 & $\mathrm{SDS}$ & 33 \\
5 & $\mathrm{AOT}$ & 37 \\
6 & Span 60 & 20 \\
7 & Tween 80 & 59 \\
8 & Triton X-100 & 60 \\
9 & TPGS-750-M & 60 \\
10 & Didodecyldimethylammonium & 62 \\
& bromide (DDAB) & 38 \\
11 & Cetylpyridinium chloride & 42 \\
12 & Dioctadecylammonium & \\
& bromide (DODAB) & 40 \\
& 3-(N,N-Dimethylmyristylammonio)-
\end{tabular}

${ }^{a}$ Reaction conditions: $p$-methoxybenzylamine (3a, $\left.0.5 \mathrm{mmol}\right)$, isovaleraldehyde (2a, $0.5 \mathrm{mmol}$ ), phenylacetic acid (1a, $0.5 \mathrm{mmol}), p$ methoxybenzyl isocyanide (4a, $0.5 \mathrm{mmol})$ and additive $(0.1 \mathrm{mmol})$ in 5 $\mathrm{mL}$ distilled water for $48 \mathrm{~h}$ at room temperature. ${ }^{b}$ Isolated yield of $5 \mathbf{a}$.

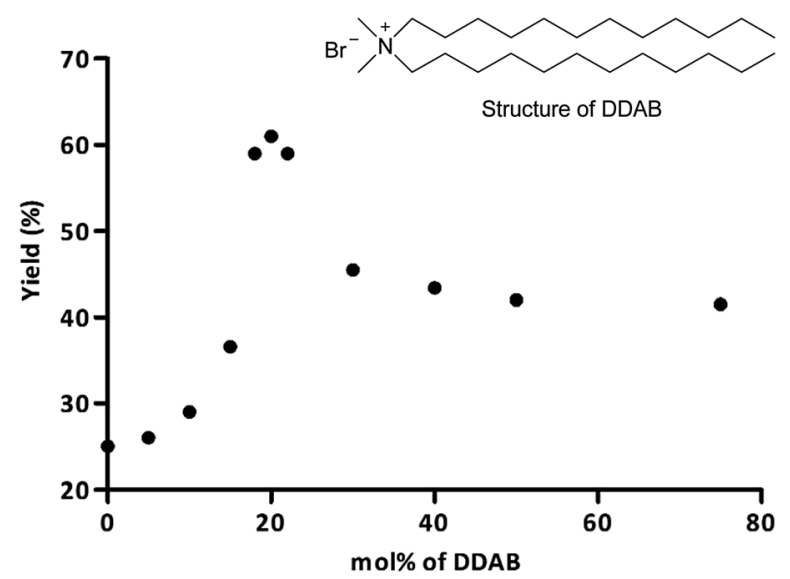

Fig. 1 Effect of amount of DDAB on the yield of $5 a$ in the model Ugi reaction. Reaction conditions: $p$-methoxybenzylamine $(3 a, 0.5 \mathrm{mmol})$, isovaleraldehyde (2a, $0.5 \mathrm{mmol})$, phenylacetic acid (1a, $0.5 \mathrm{mmol}), p$ methoxybenzyl isocyanide $(4 \mathrm{a}, 0.5 \mathrm{mmol})$ and surfactant $(0.1 \mathrm{mmol})$ in $5 \mathrm{~mL}$ distilled water for 48 h. $20 \mathrm{~mol} \%$ DDAB corresponds to the amount of substrates (0.1 M).

most effective additive (entry 10;62\%) and it was subsequently used for further experiments. DDAB is a quaternary ammonium salt with two dodecyl chains. It forms bilayered vesicles in water. The critical concentration for vesicle formation (cvc) is below $10^{-5} \mathrm{M}^{30}$ Enhancement of the reaction yield may be justified by an increase of the reactants solubility in the hydrophobic part of the aggregates, the increased concentration of the reacting species in the hydrophobic area of the assembly, and electrostatic attractions between the cationic surface of the vesicles and acid ions. ${ }^{31}$

For gaining more insight into the effect of DDAB on the model Ugi reaction, the reaction was studied by varying the
DDAB concentration from 0 to $75 \mathrm{~mol} \%$. All used concentrations of DDAB were above the critical aggregate formation concentration $\left(1.5 \times 10^{-4} \mathrm{M}\right) .{ }^{30}$ The results are shown in Fig. 1 . Also the influence of different concentrations of Triton X-100 was investigated. However the reaction yields were lower than in the presence of DDAB; the results are presented in ESI. $\dagger$ In all cases, the reaction yield in the presence of DDAB was higher than in distilled water. While upon increasing the amount of DDAB from 0 to $20 \mathrm{~mol} \%$, the yield of product 5a significantly increased up to $62 \%$. Further elevation of the DDAB concentration caused a decrease in the reaction yield to $59 \%$ (22 mol\%) and about $45 \%(30-75 \%)$. These data allowed to choose the optimal amount of DDAB (20 mol\%) for all following research. Analogous studies performed using Triton X-100 revealed that $20 \mathrm{~mol} \%$ is also the optimal concentration for this surfactant (see in $\mathrm{ESI} \dagger$ ). As mentioned above, for the optimal concentration of DDAB (20 mol\%) product 5a was obtained with higher yield than in the case of methanol as solvent (62\% vs. 55\%).

Very important from an ecological point of view is the reusability of the additive ("catalyst"). For this reason, we investigated if the DDAB vesicular suspension can be used more than once. The model reaction was carried out with 1a, 2a, 3a and 4a for $48 \mathrm{~h}$ in the presence of $20 \mathrm{~mol} \%$ of DDAB. During the progress of the reaction, crystals of product $5 \mathbf{a}$ were forming and falling out from the reaction mixture. The crystals were separated by filtration. The filtrate containing surfactant was then used for a next reaction run. The precipitate of 5a was purified by recrystallization from hexane/ethyl acetate. The results are summarized in Fig. 2. The DDAB vesicle suspension was used for four consecutive reaction cycles. There was a gradual decrease in reaction yield from $62 \%$ to $32 \%$, probably caused by the loss of surfactant during filtration. In any case, the experiments show that the vesicle suspension can be used only once without supplement of the lost DDAB.

Moreover, applying the same model reaction, the reusability of Triton X-100 was investigated. After the $3^{\text {rd }}$ run a significant decrease in reaction efficiency was observed, providing product 5a with only $10 \%$ yield. Due to this observation DDAB was

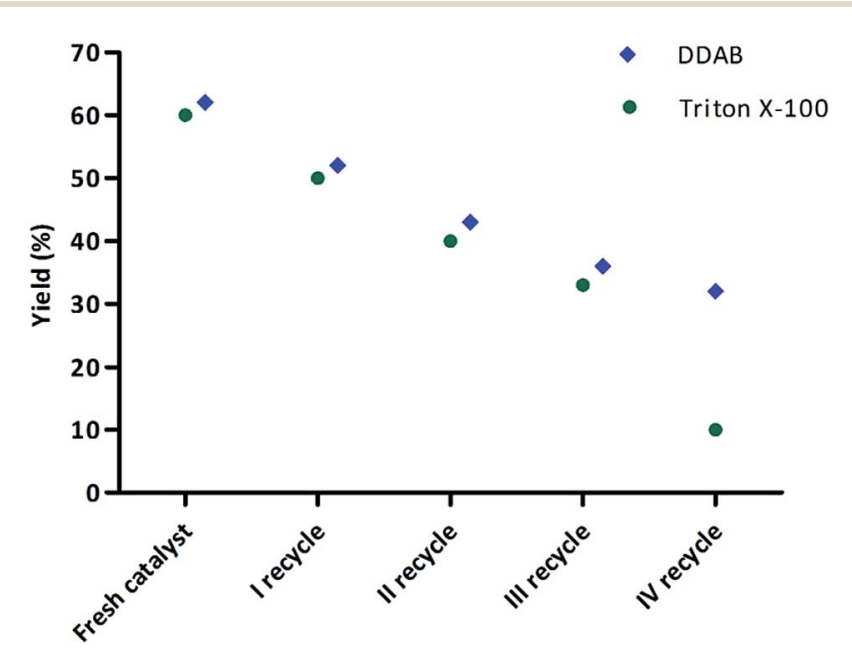

Fig. 2 Reusability of DDAB and Triton X-100 as determined through the isolated yield of $5 \mathrm{a}$ for the model Ugi reaction. 


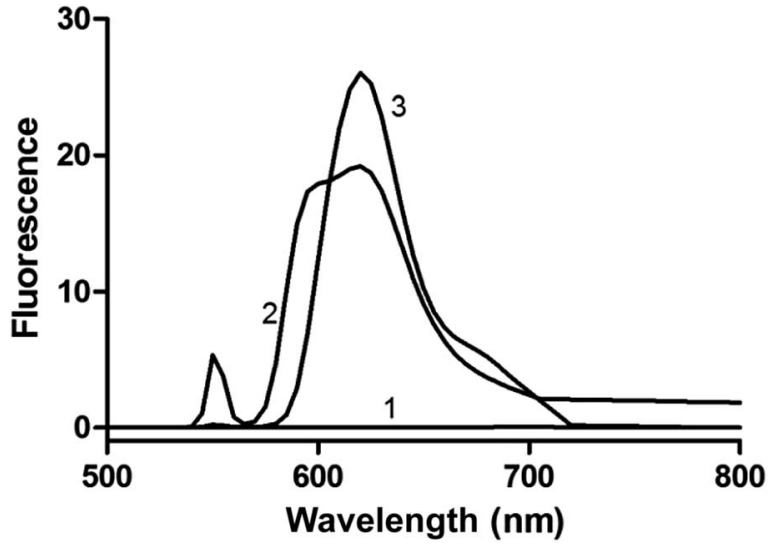

Fig. 3 Fluorescence spectra of Dil (1 mM) in water (1), Dil (1 mM) in $20 \mathrm{mM}$ DDAB dispersed in water (2), and Dil (1 mM) added to a reaction mixture in the presence of DDAB $(20 \mathrm{mM})$ containing $1 \mathrm{a}, 2 \mathrm{a}, 3 \mathrm{a}$, and $4 a$ each $100 \mathrm{mM}$ in water (3); $\lambda_{\mathrm{ex}}=550 \mathrm{~nm}$.

considered as a more suitable surfactant for the Ugi reaction than Triton X-100.

To confirm the presence of DDAB aggregates in the reaction medium, 1,1' -dioctadecyl-3,3,3',3'-tetramethylindo-carbocyanine perchlorate (DiI) was used as fluorescent probe. DiI and similar compounds are often used for labelling and imaging bilayer membranes. ${ }^{32}$ According to literature data, DiI has weak fluorescence in water, ${ }^{33}$ but in the presence of aggregates exhibits fluorescence. ${ }^{34}$ We performed three separate experiments with DiI: first, only with distilled water, second, with water and DDAB (20 $\mathrm{mM}>$ cac), and third, with water and the reactants 1a, 2a, 3a and 4a. All fluorescence spectra were recorded at an excitation wavelength $\left(\lambda_{\text {ex }}\right)$ of $550 \mathrm{~nm}$. The results are presented in Fig. 3. When DiI ( $1 \mathrm{mM}$ ) was added to distilled water, there was no detectable fluorescence. However, when DDAB (20 mM) and DiI (1 $\mathrm{mM})$ were added to water, fluorescence was observed, indicating the presence of aggregates (micelles and/or vesicles). Also when all reactants $(\mathbf{1 a}, \mathbf{2 a}, 3 \mathbf{a}$ and $\mathbf{4 a})$ and DiI were present in the sample, fluorescence was again observed, which is a clear evidence for the existence of DDAB aggregates in the reaction mixture.

In order to confirm the obtained results, the formation of micellar or vesicular aggregates was determined by DLS (dynamic light scattering) measurements. ${ }^{35}$ Exemplary results are presented in Fig. 4. As can be seen, time correlation functions, TCFs, are not monoexponential suggesting that aggregates of different sizes were present in the samples. For an aqueous solution a)

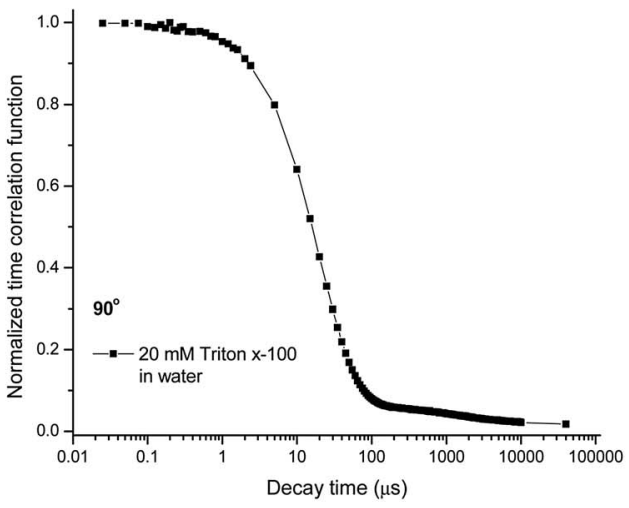

c)

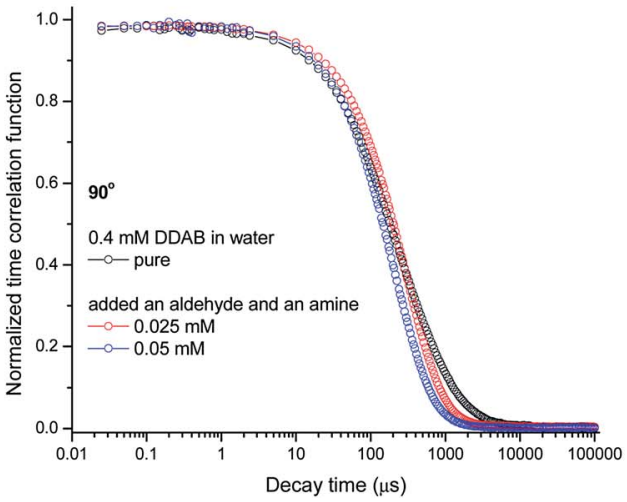

b)

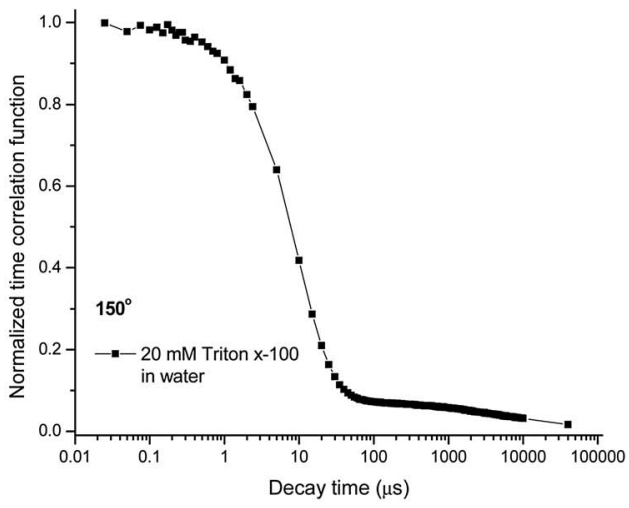

d)

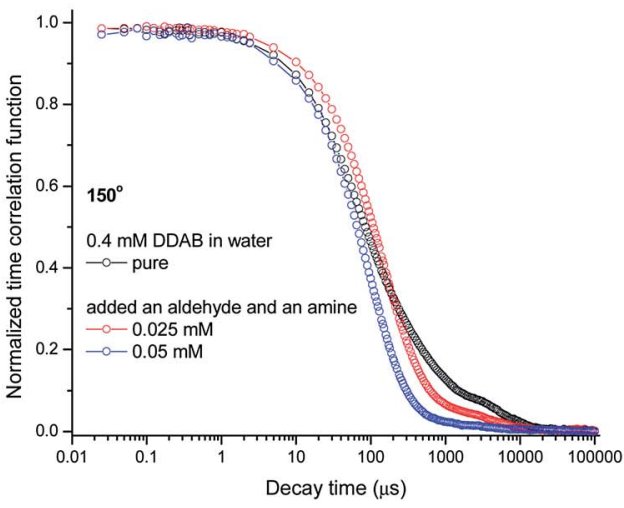

Fig. 4 Normalized time correlation functions $g_{2}(q, t)$ as a function of time $t$ for solutions of Triton X-100 (20 mM) in water at a scattering angle of $90^{\circ}$ (a) and $150^{\circ}$ (b); for suspensions of DDAB ( $4 \mathrm{mM}$ ) in pure water and with added aldehyde $2 \mathrm{a}$ and amine $3 \mathrm{a}$ (each either $0.025 \mathrm{mM}$ or $0.05 \mathrm{mM}$ ) at a scattering angle of $90^{\circ}$ (c) and $150^{\circ}$ (d). 
Table 3 Diffusion coefficients $\left(D_{c}\right)$ and hydrodynamic radii $\left(R_{h}\right)$ of aqueous micellar Triton $X-100$ solutions and DDAB vesicle suspensions, in absence and presence of aldehyde $2 \mathrm{a}$ and amine $3 \mathrm{a}$

\begin{tabular}{lllll}
\hline & & $4 \mathrm{mM}$ DDAB & & \\
\cline { 4 - 5 }$D_{\mathrm{c}} \times 10^{-10}\left(\mathrm{~m}^{2} \mathrm{~s}^{-1}\right)\left[R_{\mathrm{h}}(\mathrm{nm})\right]$ & $20 \mathrm{mM}$ Triton X-100 & $+0 \mathrm{mM}(2 \mathbf{2 a}, 3 \mathbf{a})$ & $+0.025 \mathrm{mM}(\mathbf{2 a}, 3 \mathbf{3})$ & $+0.05 \mathrm{mM}(\mathbf{2 a}, \mathbf{3 a})$ \\
\hline$D_{\mathrm{c} 1}\left[R_{\mathrm{h} 1}\right]$ & $5.67[3.41]$ & $1.69[10.59]$ & $1.83[9.90]$ & $2.00[9.08]$ \\
$D_{\mathrm{c} 2}\left[R_{\mathrm{h} 2}\right]$ & $0.01[1572.13]$ & $0.25[73.10]$ & $0.51[35.62]$ & $0.75[24.18]$ \\
$D_{\mathrm{c} 3}\left[R_{\mathrm{h} 3}\right]$ & - & $0.02[841.88]$ & $0.06[301.66]$ & $0.08[231.38]$
\end{tabular}

containing $20 \mathrm{mM}$ Triton X-100 two well separated decay modes (Fig. 4a and b) were observed $\left(g_{2}(\tau)=A_{1} \exp \left(-\Gamma_{1} t\right)+A_{2} \exp \left(-\Gamma_{2} t\right)^{2}\right.$ with decay constants $\Gamma_{1}$ and $\Gamma_{2}$ ). The fast mode corresponding to small aggregates with a diffusion coefficient $D_{\mathrm{c} 1}=5.67 \times 10^{-10}$ $\mathrm{m}^{2} \mathrm{~s}^{-1}$, and the slow one corresponding to large aggregates with $D_{\mathrm{c} 2}=0.01 \times 10^{-10} \mathrm{~m}^{2} \mathrm{~s}^{-1}$ (see Table 3). The hydrodynamic radii of the aggregates were $3.41 \mathrm{~nm}$ and $1572 \mathrm{~nm}$ respectively. The ratios of the pre-exponential terms of the TCFs indicate that in the solution of Triton X-100 mainly small aggregates were present (micelles).

At $20 \mathrm{mM}$ of DDAB DLS measurements were not possible (see in ESI $\dagger$ ) due to the high turbidity of this suspension. Dilution of such heterogeneous samples is necessary before the measurements, which, however, may lead to changes in the aggregate size and morphology. Nevertheless, a DLS analysis of a $4 \mathrm{mM}$ suspension of DDAB in pure water was carried out. The presence of three well separated assemblies with diffusion coefficients $0.25 \times 10^{-10} \mathrm{~m}^{2}, 1.69 \times 10^{-10} \mathrm{~m}^{2} \mathrm{~s}^{-1}$, and $0.02 \times 10^{-10}$ $\mathrm{m}^{2} \mathrm{~s}^{-1}$ was observed. The hydrodynamic radii of the species present in solution were $10.6 \mathrm{~nm}, 73.1 \mathrm{~nm}$, and $842 \mathrm{~nm}$, respectively. The smallest objects are probably micelles while the larger ones are of vesicular type. Addition of a mixture of aldehyde 2a and amine 3a shifted the TCFs to shorter decay times (see Fig. 4c and d) what clearly indicated that the size of the aggregates changed. The calculated hydrodynamic radii for solutions with added $0.025 \mathrm{mM}$ and $0.05 \mathrm{mM}$ of the mixture of aldehyde and amine are presented in Table 3 and Fig. 5 . The

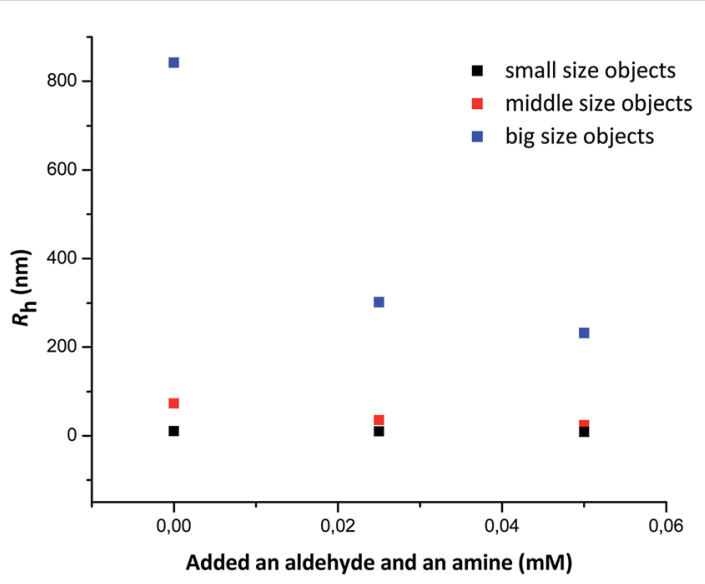

Fig. 5 The hydrodynamic radii of the DDAB aggregates as a function of the amount of added mixture of aldehyde and amine, as determined by DLS. results mainly showed that the size of the large vesicles changed. The ratios of the pre-exponential terms of the TCFs indicated that in the aqueous DDAB system mainly aggregates of medium size were present.

After optimization of the reaction conditions the versatility and scope of this new protocol was evaluated. The U-4CR was carried out with a number of different carboxylic acids (1), aldehydes (2), amines (3) and isocyanides (4) to afford corresponding $\alpha$-aminoacyl amides $(\mathbf{5 a}-\mathbf{z})$. The isolated yields were determined after $48 \mathrm{~h}$ at room temperature and were compared with the reactions conducted in distilled water. The results are summarized in Table 4.

For the first part of the experiments the effect of different carboxylic acids was evaluated. The model reaction carried out with phenylacetic acid gave slightly higher yield (product 5a, $62 \%$ ) than with benzoic acid (product $5 \mathbf{b} ; 59 \%$ ) in presence of DDAB. In water alone product $\mathbf{5 b}$ was obtained with $23 \%$ yield. Whereas application of 3-phenylpropionic acid in the presence of DDAB lead to product 5c with significantly higher yield $(81 \%)$, than in water alone $(55 \%)$. On the other hand, the reaction carried out with acetic acid gave product 5d with moderate yield (28\%) in the presence of DDAB and $20 \%$ without it. The fact that with acetic acid the yield is low could be related to the high solubility in water of this acid that is not going to be dissolved in the bilayer where all the other substrates are compartmentalized. The reaction carried out with lipophilic, high-melting stearic acid provided product $5 \mathbf{e}$ with lower yield $(20 \%)$ but still twice higher than in pure water $(9 \%)$. Reactions with acetaldehyde, propionaldehyde, butyraldehyde and isobutyraldehyde, provided products $\mathbf{5} \mathbf{f}-\mathbf{5 i}$ with very good yields $57-68 \%$, besides less than $50 \%$ in water alone. However usage of dodecanal resulted in product $\mathbf{5 j}$ with low yield ( $22 \%$ in the presence of DDAB and $12 \%$ in water). Replacing isovaleraldehyde with benzaldehyde resulted in product $5 \mathbf{k}$ with much lower yield (35\%). Changing $p$-methoxybenzyl amine to benzyl amine in the presence of DDAB provided product $\mathbf{5 l}$ with slightly lower yield $(60 \%)$ to that obtained in model reaction for $p$-methoxybenzylamine (product 5a, 62\%). Reactions carried out with $n$-butylamine, isobutylamine and $n$-hexylamine resulted in products $\mathbf{5 m}, \mathbf{5 n}$ and $\mathbf{5 o}$ with substantially lower yields (30$53 \%)$ than with $p$-methoxybenzylamine. The observed decrease in the reaction yields may be caused by lower nucleophilicity of the aliphatic amine and/or its lower hydrophobicity.

Changing the isocyanide in the model reaction to benzyl isocyanide resulted in compound $\mathbf{5 p}$ with $\mathbf{7 9 \%}$ yield, while the 
Table 4 Influence of DDAB and Triton X-100 on the U-4CR reaction of different reactants

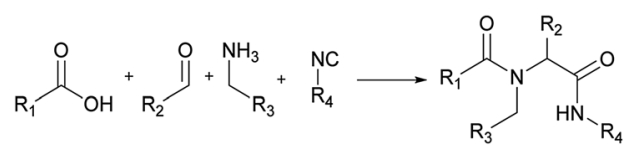
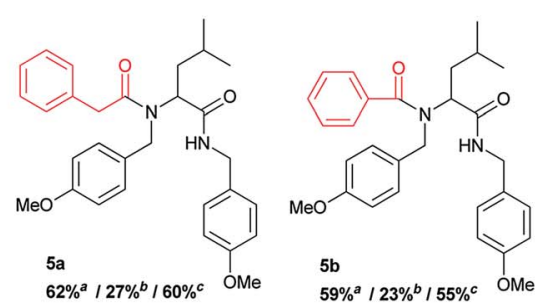

$\begin{array}{lll}2 & 3 & 4\end{array}$

5<smiles>COc1ccc(CCN(Cc2ccc(OC)cc2)C(C)C(=O)NCc2ccccc2)cc1</smiles><smiles>CCC(C=O)NC(=O)Cc1ccccc1</smiles><smiles>CNCc1ccc(OC)cc1</smiles><smiles>COc1ccc(CNC(=O)C(CC(C)C)N(Cc2ccc(OC)cc2)C(=O)CCc2ccccc2)cc1</smiles><smiles>COc1ccc(CNC(=O)C(CC(C)C)N(Cc2ccc(OC)cc2)C(C)=O)cc1</smiles><smiles>CCCCOc1ccc(CNC(=O)C(CC(C)C)N(Cc2ccc(OC)cc2)C(C)=O)cc1</smiles>

$65 \%^{a} / 13 \%^{b} / 56 \%^{c}$

$57 \%^{a / 12 \% b} / 48 \% c$<smiles>CCCC(C(=O)NCc1ccc(OC)cc1)N(Cc1ccc(O)cc1)C(=O)Cc1ccccc1</smiles><smiles>COc1ccc(CNC(=O)C(C(C)C)N(Cc2ccccc2)C(=O)Cc2ccc(OC)cc2)cc1</smiles><smiles>CCC(C(=O)NCc1ccc(OC)cc1)N(Cc1ccc(OC)cc1)C(=O)Cc1ccccc1</smiles><smiles>COc1ccc(CNC(=O)[C@@H](c2ccccc2)N(Cc2ccc(OC)cc2)C(=O)Cc2ccccc2)cc1</smiles><smiles>COc1ccc(CNC(=O)C(CC(C)C)N(Cc2ccccc2)C(=O)Cc2ccccc2)cc1</smiles><smiles>CCCCN(C(=O)Cc1ccccc1)C(CC(C)C)C(=O)NCc1ccc(C)cc1</smiles><smiles>COc1ccc(CNC(=O)[C@H](CC(C)C)N(CC(C)C)C(=O)Cc2ccccc2)cc1</smiles>
$43 \% \%^{a} /<5 \%$ । $35 \% \%$<smiles>CCCN(C(=O)Cc1ccccc1)C(CC(C)C)C(=O)NCc1ccc(OC)cc1</smiles><smiles>COc1ccc(CN(C(=O)Cc2ccccc2)C(CC(C)C)C(=O)NCc2ccccc2)cc1</smiles><smiles>COc1ccc(CN(C(=O)Cc2ccccc2)C(CC(C)C)C(=O)Nc2ccc(Oc3ccc(OC)cc3)cc2)cc1</smiles><smiles>COc1ccc(CN(C(=O)c2ccccc2)C(CC(C)C)C(=O)Nc2ccc(F)cc2)cc1</smiles><smiles>Cc1cc(C)cc(CN(C(=O)Cc2ccccc2)C(CC(C)C)C(=O)NC2CCCCC2)c1</smiles>

$79 \%^{\circ / 35 \%} \%^{b} / 39 \%^{c}$

$0 / 10$

0/0/0

$62 \%^{a} / 32 \%^{b} / 45 \%^{c}$

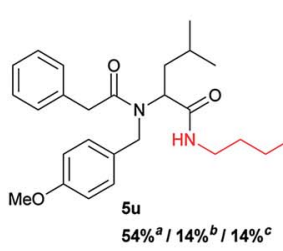

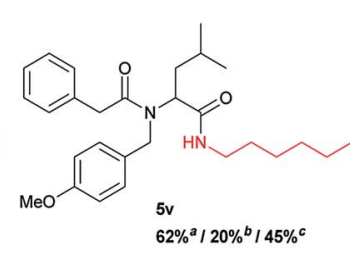

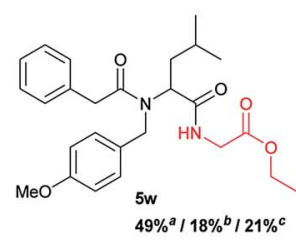<smiles>COc1cccc(CNC(=O)C(CC(C)C)N(Cc2ccc(O)cc2)C(=O)Cc2ccccc2)c1</smiles>

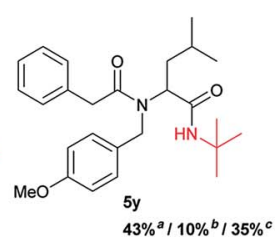

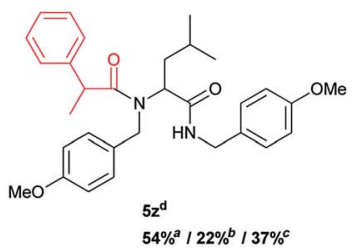

${ }^{a}$ Reaction carried out in $5 \mathrm{~mL}$ distilled water in presence of DDAB (20 mol\%) for $48 \mathrm{~h} .{ }^{b}$ Reaction carried out in $5 \mathrm{~mL}$ distilled water for $48 \mathrm{~h}$.

${ }^{c}$ Reaction carried out in the presence of Triton X-100 (20 mol\%) for $48 \mathrm{~h} .{ }^{d}$ Mixture of diastereoisomers, $\mathrm{dr}=1: 0.75$, determined by ${ }^{1} \mathrm{H}$ NMR. 
reaction with cyclohexyl isocyanide gave compound $5 \mathbf{t}$ with $62 \%$ yield. When 2,4-dimethoxybenzyl isocyanide was used, product $5 \mathbf{x}$ was obtained with $62 \%$ yield. The change of isocyanide had only a slight influence on the Ugi reaction carried out both in aqueous DDAB suspension or in water alone. Reactions carried out with isocyanobenzene (5q) and 4-nitroisocyanobenzene (5r) and 4-fluoroisocyanobenzene (5s) did not give the expected products neither in the presence of DDAB nor in water alone. Next, we tested the influence of aliphatic isocyanides. The reaction with butyl isocyanide, provided product $5 \mathbf{u}$ with good yield $(54 \%)$ and with hexyl isocyanide, product $5 \mathbf{v}$ with a little higher yield (62\%). However use of ethyl isocyanoacetate and tert-butyl isocyanide give the compounds $5 \mathbf{w}$ and $\mathbf{5 y}$ ( $49 \%$ and $43 \%$, respectively).

Finally, the possible influence of DDAB on the diastereoselectivity of the U-4CR was studied using isovaleraldehyde (2a), $p$-metoxybenzylamine (3a), 2-phenylpropionic acid and $p$ methoxybenzyl isocyanide (4a). No differential in the diasteroselectivity ratios for the product $\mathbf{5 z}$ obtained in the presence of DDAB or in water was observed. In both cases the diastereoisomeric ratio for $\mathbf{5 z}$ was the same $1: 0.75$.

For better understanding the influence of the added surfactants on the Ugi reaction, we compared the results obtained in the cationic DDAB and the non-ionic surfactant Triton X-100 systems. For both surfactants very similar yields were obtained for the model reaction. However, when we investigated different derivatives, we received lower yields with Triton-X-100 for the majority of compounds. Only products $\mathbf{5 d}$ and $\mathbf{5 j}$ were obtained with the same yield as in the presence of DDAB vesicles $(28 \%$ and $22 \%$, respectively). Overall, definitively higher

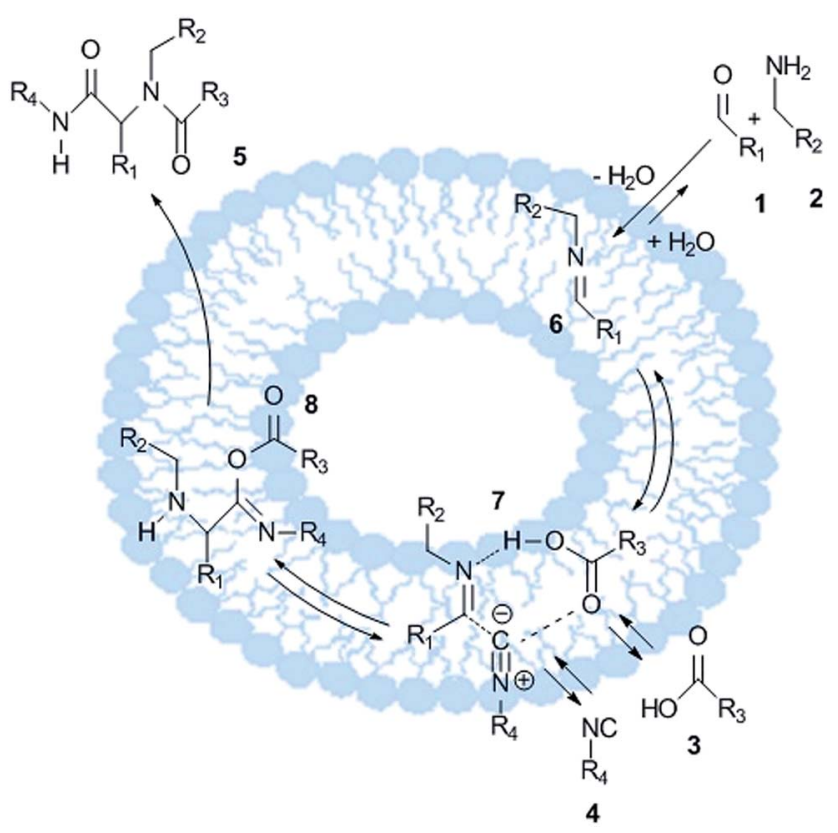

Scheme 1 Schematic representation of a plausible mechanism for the Ugi reaction ${ }^{39}$ occurring in the DDAB vesicle system. Note that the vesicle size and membrane diameter are not drawn to scale. Without mechanical treatment, such as sonication or polycarbonate membrane extrusion, DDAB in aqueous solution forms heterogeneous micrometer-sized multilamellar vesicles. reaction yields were achieved in the presence of the vesicle forming surfactant (DDAB) ${ }^{36}$ than in the presence of Triton $\mathrm{X}-100$ forming micelles. ${ }^{37}$

A plausible mechanism of the U-4CR in the presence of DDAB vesicles is shown in Scheme 1. We assume that, the first step of the reaction involves the condensation of the aldehyde and the amine to the imine $\mathbf{6}$, the formed water molecule is released to the hydrophilic medium, thereby shifting the equilibrium towards imine $6^{38}$ Moreover, the hydrophobic environment inside the vesicles can enhance the formation of the postulated complex 7 of the imine 6 , the carboxylic acid $\mathbf{3}$ and the isocyanide 4 . In the next step, the nucleophilic acid anion and the isocyanide are added to the electrophilic iminium ion, which leads to intermediate 8 . The final product $\mathbf{5}$ is realized after an intramolecular Mumm rearrangement of intermediate $3{ }^{39}$ Afterwards, product 5 precipitates from the reaction medium, which may also enhance the reaction efficiency.

\section{Conclusions}

A new, alternative protocol for the synthesis of $\alpha$-aminoacyl amides was achieved by using aqueous surfactant systems. The influence of different surfactants on the course of Ugi reaction was investigated. We found that the presence of cationic DDAB and non-ionic Triton X-100, Tween 80 and TPGS-750-M surfactants have a beneficial effect on the reaction efficiency if compared to distilled water. A comparison of the two most efficient surfactants, DDAB and Triton X-100, was made. In most cases the presence of DDAB vesicles resulted in higher reaction yields than in the presence of Triton X-100 micelles.

For both, the DDAB and the Triton X-100 systems, detailed studies of the surfactant concentration dependence and the surfactant reusability were carried out. The obtained results revealed that DDAB at the amount of $20 \mathrm{~mol} \%$ was the most suitable for the Ugi reaction. After careful optimized reaction conditions the effect of substrate variation was studied, providing 23 fully characterized $\alpha$-aminoacyl amides.

To confirm the presence of aggregates, micelles or vesicles, DLS and fluorescence measurements were performed. The obtained results showed for Triton X-100 the presence of mainly small aggregates (micelles). For the DDAB suspension larger aggregates were found to be present, in agreement with the expected presence of vesicles. An influence of the presence of an imine (obtained through a reaction of $2 \mathbf{a}$ with $3 \mathbf{a}$ ) on the diffusion coefficients and the hydrodynamic radii of aggregates was observed.

Further studies towards an application of the investigated systems have been initiated.

\section{Experimental}

${ }^{1} \mathrm{H}$ NMR and ${ }^{13} \mathrm{C}$ NMR spectra were recorded in $\mathrm{CDCl}_{3}$ with Bruker $400 \mathrm{MHz}$ spectrometers. Tetramethylsilane (TMS) was used as internal standard. TLC was performed on Kieselgel 60 F254 aluminum sheets. Melting points were determined with a model SMP-20 device (Büchi, Flawil, Swizerland). Fluorescence spectra were recorded in quartz cuvettes with an F-7000 
spectrofluorometer (Shimadzu, Kyoto, Japan). The DLS experiments were carried out on a BI-200SM goniometer (Brookhaven Instruments Corp.) equipped with the $2 \mathrm{~W}$ Spectra Physics Stabilite 2017 Argon ion laser (wavelength $\lambda=514.5 \mathrm{~nm}$ linearly polarized). Scattered light was collected at various angles (50$150^{\circ}$ ) with photon-counting PMT and processed by a Ccontrolled 522-channel BI-9000 AT correlator. The temperature of the sample was kept constant by being surrounded with a temperature-controlled tank containing index-matching liquid (decahydronaphthalene). The tank temperature was thermostated with circulating water at $25{ }^{\circ} \mathrm{C}( \pm 0.01)$. The homodyne intensity correlation function $g_{2}$ was collected in the measurements. The decay constant $\Gamma=q^{2} D_{\mathrm{c}}(q=(4 \pi n / \lambda) \sin (\theta)$ 2), $n$ - refractive index of the solution, $\lambda$ - wavelength of the laser, $\theta$ - scattering angle) of the time correlation functions (TCFs) was plotted against $q^{2}$ to obtain the collective diffusion coefficient $D_{\mathrm{c}}$. The hydrodynamic radius $\left(R_{\mathrm{h}}\right)$ was calculated by applying the Stokes-Einstein equation $R_{\mathrm{h}}=k T / 6 \pi \eta D_{\mathrm{c}}(\eta-$ viscosity of a solution, $T$ - absolute temperature). The refractive index of all samples was measured on a digital multiple wavelength refractometer (DSR- $\lambda$ ) from SCHMIDT-HAENSCH with an accuracy of $\pm 0.0001 \mathrm{nD}$ at $514.5 \mathrm{~nm}$. The viscosity of the surfactant solutions was measured using the Falling Ball Viscometer KF10 from RheoTecMesstechnik GmbH.

Almost all chemicals were commercial available. Only $p$ methoxybenzyl isocyanide, hexylisocyanide and 2,4-dimethoxybezylisocyanide were synthesized from corresponding amines in two-step syntheses. Dilauryldimethylammonium bromide (=didodecyldimethylammonium bromide, purity $>98.0 \%$ ), was purchased from TCI, product number D1974. Dioctadecyldimethylammonium bromide (DODAB), purity $\geq$ 98.0\% (AT), was purchased from Sigma Aldrich, product number 40165 . Dioctylsulfosuccinate sodium salt (AOT = sodium bis(2-ethylhexyl) sulfosuccinate, purity 98\%), was purchased from Sigma Aldrich, product number 323 586. Sorbitan monostearate (Span 60), was purchased from TCI, product number GL01-YQ. Tween 80, was purchased from Schuchardt München (now Merck). Sodium dodecyl sulfate (SDS), purity $\geq$ 99.0\% (GC), was purchased from Sigma Aldrich, product number L6026. Triton X-100, was purchased from Sigma Aldrich, product number T9284. TPGS-750-M (DL- $\alpha$-tocopherol methoxypolyethylene glycol succinate) was purchased from Sigma Aldrich, product number 763896.

\section{General procedure A for product 5a-n (with DDAB as additive)}

An aldehyde $(0.5 \mathrm{mmol})$ and an amine $(0.5 \mathrm{mmol})$ were added to $5 \mathrm{~mL}$ distilled water in the presence of DDAB $(0.1 \mathrm{mmol})$. After 10 minutes, a carboxylic acid $(0.5 \mathrm{mmol})$ and then after another 10 minutes an isocyanide $(0.5 \mathrm{mmol})$ were added. The mixture was stirred for $48 \mathrm{~h}$ at room temperature. After extraction with ethyl acetate $(3 \times 20 \mathrm{~mL})$, the resulting combined organic layers were dried with $\mathrm{MgSO}_{4}$ and then the solvent was removed by distillation under reduced pressure. The product was purified by column chromatography (silica gel, hexane/AcOEt).

For the reactions in the presence of other surfactants than DDAB, the same protocol was used, whereby DDAB was replaced.
Product 5a. White powder; mp. $106-107{ }^{\circ} \mathrm{C} ;{ }^{1} \mathrm{H}$ NMR (400 $\left.\mathrm{MHz} ; \mathrm{CDCl}_{3}\right) \delta \mathrm{ppm}=7.19(4 \mathrm{H}, \mathrm{m}, \mathrm{Ph}), 7.01(5 \mathrm{H}, \mathrm{m}, \mathrm{Ph}), 6.77$ $(5 \mathrm{H}, \mathrm{m}, \mathrm{Ph}, \mathrm{CH}), 6.71(1 \mathrm{H}, \mathrm{s}, \mathrm{CH}), 4.94(1 \mathrm{H}, \mathrm{t}, \mathrm{NH}), 4.44(2 \mathrm{H}, \mathrm{s}$; $\left.\mathrm{CH}_{2}\right)$, 4.16-4.20 (2H, m, $\left.\mathrm{CH}_{2}\right), 3.73\left(6 \mathrm{H}, \mathrm{s}, \mathrm{CH}_{3}\right), 3.55(2 \mathrm{H}, \mathrm{d}$, $\mathrm{CH}_{2}$ ), 1.79-1.83 (1H, m, CH), 1.37-1.43 (2H, m, $\left.\mathrm{CH}_{2}\right), 0.75-0.79$ $\left(6 \mathrm{H}, \mathrm{m}, \mathrm{CH}_{3}\right) ;{ }^{13} \mathrm{CNMR}\left(100 \mathrm{MHz} ; \mathrm{CDCl}_{3}\right) \delta \mathrm{ppm}=22.41,22.73$, 25.14, 37.01, 41.31, 42.83, 48.24, 55.26, 56.55, 114.02, 114.23, $126.95,127.29,128.64,128.76,128.81,128.97,129.01,129.24$, 130.30, 134.56, 158.92, 170.52, 173.42; HRMS calcd for $\mathrm{C}_{30} \mathrm{H}_{36} \mathrm{~N}_{2} \mathrm{O}_{4} \mathrm{Na}[\mathrm{M}+\mathrm{Na}]^{+}: 511.2573$ found: 511.2574 .

Product 5b. Pale yellow oil; ${ }^{1} \mathrm{H} \mathrm{NMR}\left(400 \mathrm{MHz}, \mathrm{CDCl}_{3}\right) \delta \mathrm{ppm}$ $=7.04-7.29(9 \mathrm{H}, \mathrm{m}, \mathrm{Ph}), 6.61-6.78(5 \mathrm{H}, \mathrm{m}, \mathrm{Ph}+\mathrm{CH}), 4.74(1 \mathrm{H}, \mathrm{s}$, $\mathrm{NH}), 4.41\left(2 \mathrm{H}, \mathrm{s}, \mathrm{CH}_{2}\right), 4.17\left(2 \mathrm{H}, \mathrm{m}, \mathrm{CH}_{2}\right), 3.66-3.72(6 \mathrm{H}, \mathrm{m}, 2 \times$ $\left.\mathrm{CH}_{3}\right), 1.81\left(2 \mathrm{H}, \mathrm{s}, \mathrm{CH}_{2}\right), 1.57(1 \mathrm{H}, \mathrm{s}, \mathrm{CH}), 0.85\left(6 \mathrm{H}, \mathrm{s}, 2 \times \mathrm{CH}_{3}\right)$; ${ }^{13} \mathrm{C}$ NMR $\left(100 \mathrm{MHz} ; \mathrm{CDCl}_{3}\right) \delta \mathrm{ppm}=22.17,22.73,25.07,37.27$, 42.77, 51.12, 55.12, 55.19, 57.95, 113.74, 113.94, 126.69, 128.46, 128.82, 128.98, 129.20, 129.79, 130.45, 136.24, 158.84, 170.67, 173.79; HRMS calcd for $\mathrm{C}_{29} \mathrm{H}_{34} \mathrm{~N}_{2} \mathrm{O}_{4} \mathrm{Na}[\mathrm{M}+\mathrm{Na}]^{+}: 497.2416$ found: 497.2410 .

Product 5c. White powder; mp. $78-79{ }^{\circ} \mathrm{C} ;{ }^{1} \mathrm{H}$ NMR $(400 \mathrm{MHz}$; $\left.\mathrm{CDCl}_{3}\right) \delta \mathrm{ppm}=6.74-7.26(14 \mathrm{H} \mathrm{m}, \mathrm{Ph}+\mathrm{CH}), 5.01(1 \mathrm{H}, \mathrm{m}, \mathrm{NH})$, $4.43\left(2 \mathrm{H}, \mathrm{m}, \mathrm{CH}_{2}\right)$ 4.23-4.30 $\left(2 \mathrm{H}, \mathrm{m}, \mathrm{CH}_{2}\right), 3.78\left(6 \mathrm{H}, \mathrm{s}, \mathrm{CH}_{3}\right)$, 2.86-2.91 (2H, m, $\left.\mathrm{CH}_{2}\right), 2.53-2.58\left(2 \mathrm{H}, \mathrm{m}, \mathrm{CH}_{2}\right), 1.81-1.85(1 \mathrm{H}$, $\mathrm{m}, \mathrm{CH}), 1.40-1.44\left(2 \mathrm{H}, \mathrm{m}, \mathrm{CH}_{2}\right), 0.81-0.91\left(6 \mathrm{H}, \mathrm{m}, \mathrm{CH}_{3}\right) ;{ }^{13} \mathrm{C}$ NMR $\left(100 \mathrm{MHz} ; \mathrm{CDCl}_{3}\right) \delta \mathrm{ppm}=22.45,22.71,25.14,31.38$, 35.71 , 37.02, 42.79, 47.98, 55.26, 56.29, 114.02, 114.12, 126.19, $127.23,128.38,128.44,129.00,129.34,130.44,140.86,158.80$, 170.66, 174.62 ppm; HRMS calcd for $\mathrm{C}_{31} \mathrm{H}_{38} \mathrm{~N}_{2} \mathrm{O}_{4} \mathrm{Na}[\mathrm{M}+\mathrm{Na}]^{+}$: 525.2729 found: 525.2717 .

Product 5d. White powder; mp. $123-124{ }^{\circ} \mathrm{C} ;{ }^{1} \mathrm{H}$ NMR $(400$ $\left.\mathrm{MHz} ; \mathrm{CDCl}_{3}\right) \delta \mathrm{ppm}=6.47-7.18(14 \mathrm{H}, \mathrm{m}, \mathrm{Ph}+\mathrm{CH}), 5.03(0.5 \mathrm{H}, \mathrm{s}$ br; $\left.\mathrm{NH}_{\mathrm{a}}\right), 4.80\left(0.5 \mathrm{H}, \mathrm{s}\right.$ br, $\left.\mathrm{NH}_{\mathrm{b}}\right), 4.17-4.37\left(4 \mathrm{H}, \mathrm{m}, 2 \times \mathrm{CH}_{2}\right), 3.73$ $\left(6 \mathrm{H}, \mathrm{m}, 2 \times \mathrm{CH}_{3}\right), 1.72-1.79(1 \mathrm{H}, \mathrm{m}, \mathrm{CH}), 1.24-1.33(4 \mathrm{H}, \mathrm{m}$, $\left.\mathrm{CH}_{2}\right), 0.72-0.80\left(6 \mathrm{H} \mathrm{m}, 2 \times \mathrm{CH}_{3}\right) ;{ }^{13} \mathrm{C} \mathrm{NMR}\left(100 \mathrm{MHz} ; \mathrm{CDCl}_{3}\right)$ $\delta \mathrm{ppm}=20.45,20.84,22.67,25.29,36.63$, 42.82, 43.86, 55.28, 114.02, 114.18, 114.26, 126.91, 127.09, 127.36, 128.76, 128.92, 128.96, 129.16, 158.87, 164.69, 170.61 ppm; HRMS calcd for $\mathrm{C}_{31} \mathrm{H}_{38} \mathrm{~N}_{2} \mathrm{O}_{4} \mathrm{Na}[\mathrm{M}+\mathrm{Na}]^{+}: 525.2729$ found: 525.2722.

Product 5e. Pale yellow oil; ${ }^{1} \mathrm{H}$ NMR (400 $\left.\mathrm{MHz} ; \mathrm{CDCl}_{3}\right) \delta=$ 6.73-7.08 (m, 9H; Ar, CH), 4.85-5.03 (m, 1H; -NH), 4.44 (s, 2H, $\left.\mathrm{CH}_{2}\right), 3.97-4.32\left(\mathrm{~m}, 2 \mathrm{H} ; \mathrm{CH}_{2}\right), 3.71\left(\mathrm{~s}, 6 \mathrm{H} ; \mathrm{CH}_{3}\right), 1.95(\mathrm{~s}, 3 \mathrm{H}$; $\left.\mathrm{CH}_{3}\right), 1.66-1.84(\mathrm{~m}, 1 \mathrm{H}, \mathrm{CH}), 1.29-1.52\left(\mathrm{~m}, 2 \mathrm{H} ; \mathrm{CH}_{2}\right), 0.78 \mathrm{ppm}$ $\left(\mathrm{t}, 6 \mathrm{H} ; \mathrm{CH}_{3}\right) ;{ }^{13} \mathrm{C} \mathrm{NMR}\left(100 \mathrm{MHz} ; \mathrm{CDCl}_{3}\right) \delta \mathrm{ppm}=22.42,22.74$, 25.17, 37.17, 42.79, 48.75, 55.24, 56.08, 114.00, 114.14, 127.30, 128.98, 129.34, 130.38, 158.81, 158.89, 170.69, 172.98; HRMS calcd for $\mathrm{C}_{24} \mathrm{H}_{32} \mathrm{~N}_{2} \mathrm{O}_{4} \mathrm{Na}[\mathrm{M}+\mathrm{Na}]^{+}$: 435.2260 found: 435.2260 .

Product 5f. Yellow powder; mp. 92-93 ${ }^{\circ} \mathrm{C}$; $1 \mathrm{H}$ NMR $(400 \mathrm{MHz}$; $\left.\mathrm{CDCl}_{3}\right) \delta \mathrm{ppm}=6.95-7.19(4 \mathrm{H}, \mathrm{m}, \mathrm{Ph}), 6.86(1 \mathrm{H}, \mathrm{s}, \mathrm{CH}), 6.73-6.77$ (4H, m, Ph), 4.94-4.97 (1H, m, NH), 4.43-4.44 (2H, m, $\left.\mathrm{CH}_{2}\right), 4.19-$ $4.21\left(2 \mathrm{H}, \mathrm{m}, \mathrm{CH}_{2}\right), 3.71\left(6 \mathrm{H}, \mathrm{s}, 2 \times \mathrm{CH}_{3}\right), 2.09-2.25\left(3 \mathrm{H}, \mathrm{m}, \mathrm{CH}_{3}\right)$, 1.74-1.80 (1H, m, CH), 1.39-1.45 (4H, m, $\left.\mathrm{C}_{2} \mathrm{H}_{4}\right), 1.18(31 \mathrm{H}, \mathrm{s} \mathrm{br}$, $\left.\mathrm{C}_{15} \mathrm{H}_{31}\right) ;{ }^{13} \mathrm{C} \mathrm{NMR}\left(100 \mathrm{MHz} ; \mathrm{CDCl}_{3}\right) \delta \mathrm{ppm}=14.08,22.43,22.66$, 22.74, 29.31, 29.33, 29.38, 29.47, 29.61, 29.64, 29.68, 31.90, 34.04, 55.21 , 56.20, 113.97, 114.09, 127.26, 128.97, 129.55, 130.47, 158.79, 158.87, 170.81, 175.80, 177.43; HRMS calcd for $\mathrm{C}_{40} \mathrm{H}_{64} \mathrm{~N}_{2} \mathrm{O}_{4} \mathrm{Na}[\mathrm{M}+\mathrm{Na}]^{+}: 659.4769$ found: 659.4758 . 
Product 5g. White powder; mp. $115-116{ }^{\circ} \mathrm{C} ;{ }^{1} \mathrm{H}$ NMR $(400$ $\left.\mathrm{MHz} ; \mathrm{CDCl}_{3}\right) \delta \mathrm{ppm}=7.13-7.17(4 \mathrm{H}, \mathrm{m}, \mathrm{Ph}), 6.97-7.02(5 \mathrm{H}, \mathrm{m}$, $\mathrm{Ph})$, 6.65-6.77 (5H, m, Ph + CH) 4.97-4.99 (1H, s br; NH), 4.42$4.44\left(2 \mathrm{H}, \mathrm{m}, \mathrm{CH}_{2}\right), 4.15-4.17\left(2 \mathrm{H}, \mathrm{m}, \mathrm{CH}_{2}\right), 3.69\left(6 \mathrm{H}, \mathrm{s}, 2 \times \mathrm{CH}_{3}\right)$, 3.52-3.54 (2H, m, $\left.\mathrm{CH}_{2}\right), 1.18-1.26\left(q, 3 \mathrm{H} ; \mathrm{CH}_{3}\right) ;{ }^{13} \mathrm{C}$ NMR $(100$ $\left.\mathrm{MHz} ; \mathrm{CDCl}_{3}\right) \delta \mathrm{ppm}=14.16,41.21,42.87,47.97,53.43,55.27$, 114.02 , 114.31, 126.98, 127.11, 128.71, 128.99, 129.32, 130.35, 134.59, 158.96, 171.05, 173.13; HRMS calcd for $\mathrm{C}_{27} \mathrm{H}_{30} \mathrm{~N}_{2} \mathrm{O}_{4} \mathrm{Na}$ $[\mathrm{M}+\mathrm{Na}]^{+}:$469.2103 found: 469.2092.

Product 5h. Pale yellow oil; ${ }^{1} \mathrm{H}$ NMR $\left(400 \mathrm{MHz} ; \mathrm{CDCl}_{3}\right) \delta \mathrm{ppm}$ = 7.17-6.96 (9H, m, Ph), 6.77-6.73 (5H, m, Ph + CH), 4.83-4.79 (1H, m, NH), $4.46\left(2 \mathrm{H}, \mathrm{s}, \mathrm{CH}_{2}\right), 4.20-4.15\left(2 \mathrm{H}, \mathrm{m}, \mathrm{CH}_{2}\right), 3.71$ $\left(6 \mathrm{H}, \mathrm{s}, \mathrm{CH}_{3}\right), 3.54-3.53\left(2 \mathrm{H}, \mathrm{m}, \mathrm{CH}_{2}\right), 1.89-1.85(1 \mathrm{H}, \mathrm{m}, \mathrm{CH})$, 1.48-1.46 (1H, m, CH), 1.19-1.17 $\left(2 \mathrm{H}, \mathrm{m}, \mathrm{CH}_{2}\right), 0.78-0.74(3 \mathrm{H}$, $\left.\mathrm{m}, \mathrm{CH}_{3}\right) ;{ }^{13} \mathrm{C} \mathrm{NMR}\left(100 \mathrm{MHz} ; \mathrm{CDCl}_{3}\right) \delta \mathrm{ppm}=13.83,19.67$, 30.42 , 41.26, 42.80, 48.32, 55.26, 58.21, 114.02, 114.24, 126.95, 127.29, 128.65, 128.78, 129.00, 129.30, 130.35, 134.62, 158.89, 158.92, 170.45, 173.35; HRMS calcd for $\mathrm{C}_{29} \mathrm{H}_{34} \mathrm{~N}_{2} \mathrm{O}_{4} \mathrm{Na}[\mathrm{M}+$ $\mathrm{Na}]^{+}: 497.2416$ found: 475.2409 .

Product 5i. Pale yellow oil; ${ }^{1} \mathrm{H}$ NMR (400 $\left.\mathrm{MHz} ; \mathrm{CDCl}_{3}\right) \delta \mathrm{ppm}$ = 7.19-6.93 (10H, m, Ph), 6.77-6.70 (3H, m, Ph + CH), 4.57-4.40 $\left(2 \mathrm{H}, \mathrm{m}, \mathrm{CH}_{2}\right)$ 4.29-4.24 (2H, m, $\left.\mathrm{CH}_{2}\right), 4.14-4.09(1 \mathrm{H}, \mathrm{m}, \mathrm{NH})$, $3.71\left(3 \mathrm{H}, \mathrm{m}, \mathrm{CH}_{3}\right), 3.53\left(2 \mathrm{H}, \mathrm{s}, \mathrm{CH}_{2}\right), 2.43-2.37(1 \mathrm{H}, \mathrm{m}, \mathrm{CH}), 0.86$ $\left(2 \mathrm{H}, \mathrm{m}, \mathrm{CH}_{3}\right), 0.68-0.68\left(3 \mathrm{H}, \mathrm{m}, \mathrm{CH}_{3}\right) ;{ }^{13} \mathrm{C} \mathrm{NMR}(100 \mathrm{MHz}$; $\left.\mathrm{CDCl}_{3}\right) \delta \mathrm{ppm}=19.05,19.89,27.09,41.65,42.72,55.24,55.26$, 114.03, 114.16, 126.94, 127.66, 128.57, 128.93, 129.15, 130.09, 130.35, 134.63, 158.90, 169.99, 173.67; HRMS calcd for $\mathrm{C}_{29} \mathrm{H}_{34} \mathrm{~N}_{2} \mathrm{O}_{4} \mathrm{Na}[\mathrm{M}+\mathrm{Na}]^{+}: 497.2416$ found: 475.2416 .

Product 5j. White powder; mp. 94-95 ${ }^{\circ} \mathrm{C} ;{ }^{1} \mathrm{H}$ NMR $(400 \mathrm{MHz}$; $\left.\mathrm{CDCl}_{3}\right) \delta \mathrm{ppm}=7.04-7.17(4 \mathrm{H}, \mathrm{m}, \mathrm{Ph}), 6.97-7.02(5 \mathrm{H}, \mathrm{m}, \mathrm{Ph})$, 6.79-7.70 (5H, m, Ph + CH), 4.70-4.74 (1H, m, NH), $4.47(2 \mathrm{H}, \mathrm{s}$, $\left.\mathrm{CH}_{2}\right), 4.16-4.21\left(2 \mathrm{H}, \mathrm{m}, \mathrm{CH}_{2}\right), 3.71\left(6 \mathrm{H} \mathrm{s}, 2 \times \mathrm{CH}_{3}\right), 1.89-1.92$ $(1 \mathrm{H}, \mathrm{m}, \mathrm{CH}) 1.50-1.53(1 \mathrm{H}, \mathrm{m}, \mathrm{CH}), 0.74-0.78\left(3 \mathrm{H}, \mathrm{m}, \mathrm{CH}_{3}\right) ;{ }^{13} \mathrm{C}$ NMR $\left(100 \mathrm{MHz} ; \mathrm{CDCl}_{3}\right) \delta \mathrm{ppm}=10.94,21.71,41.21,42.79$, 48.27 , 55.27, 59.96, 114.02, 114.24, 126.96, 127.28, 128.67, $128.78,129.00,129.32,130.01,130.36,134.62,158.93,170.28$, 173.35; HRMS calcd for $\mathrm{C}_{28} \mathrm{H}_{32} \mathrm{~N}_{2} \mathrm{O}_{4} \mathrm{Na}[\mathrm{M}+\mathrm{Na}]^{+}: 483.2260$ found: 483.2249 .

Product 5k. Pale yellow oil; ${ }^{1} \mathrm{H}$ NMR $\left(400 \mathrm{MHz} ; \mathrm{CDCl}_{3}\right) \delta \mathrm{ppm}$ $=7.17-7.19(4 \mathrm{H}, \mathrm{m}, \mathrm{Ph}), 7.04(5 \mathrm{H}, \mathrm{m}, \mathrm{Ph}), 6.74-7.77(5 \mathrm{H}, \mathrm{m}, \mathrm{Ph}$ $+\mathrm{CH}), 4.79(1 \mathrm{H}, \mathrm{s} \mathrm{br}, \mathrm{NH}), 4.46\left(2 \mathrm{H}, \mathrm{s}, \mathrm{CH}_{2}\right), 4.22\left(2 \mathrm{H}, \mathrm{m}, \mathrm{CH}_{2}\right)$, $3.73\left(6 \mathrm{H}, \mathrm{s}, 2 \times \mathrm{CH}_{3}\right), 3.56\left(2 \mathrm{H}, \mathrm{m}, \mathrm{CH}_{2}\right), 1.21-1.11(20 \mathrm{H}, \mathrm{m}$, $\left.\mathrm{C}_{10} \mathrm{H}_{20}\right), 0.83-0.81\left(3 \mathrm{H}, \mathrm{m}, \mathrm{CH}_{3}\right) ;{ }^{13} \mathrm{C} \mathrm{NMR}\left(100 \mathrm{MHz} ; \mathrm{CDCl}_{3}\right.$ ) $\delta \mathrm{ppm}=14.0922 .67,26.45,28.32,29.32$, 29.42, 29.49, 29.59, $31.90,41.30,42.82,48.36,55.27,114.03,114.23,126.96,127.32$, 128.66, 128.77, 129.01, 129.25, 130.32, 134.59, 158.93, 170.47, 173.39; HRMS calcd for $\mathrm{C}_{37} \mathrm{H}_{50} \mathrm{~N}_{2} \mathrm{O}_{4} \mathrm{Na}[\mathrm{M}+\mathrm{Na}]^{+}: 609.3668$ found: 609.3658 .

Product 5l. White powder; mp. 86-87 ${ }^{\circ} \mathrm{C} ;{ }^{1} \mathrm{H}$ NMR $(400 \mathrm{MHz}$; $\left.\mathrm{CDCl}_{3}\right) \delta \mathrm{ppm}=7.07-7.23\left(12 \mathrm{H}, \mathrm{m}, \mathrm{Ph}+\mathrm{C}_{2} \mathrm{H}_{2}\right), 6.63-6.85(6 \mathrm{H}$, $\left.\mathrm{m}, \mathrm{C}_{3} \mathrm{H}_{3}\right), 5.93(1 \mathrm{H}, \mathrm{s}, \mathrm{NH}), 5.75(1 \mathrm{H}, \mathrm{s}, \mathrm{CH}), 4.62(1 \mathrm{H}, \mathrm{m}, \mathrm{CH})$, $4.40(1 \mathrm{H}, \mathrm{m}, \mathrm{CH}), 3.67\left(6 \mathrm{H}, 2 \times \mathrm{s}, 2 \times \mathrm{CH}_{3}\right), 3.62\left(2 \mathrm{H}, \mathrm{m}, \mathrm{CH}_{2}\right)$; ${ }^{13} \mathrm{C} \mathrm{NMR}\left(100 \mathrm{MHz} ; \mathrm{CDCl}_{3}\right) \delta \mathrm{ppm}=41.32,43.18,55.22,55.26$, $63.46,88.50,113.74,113.91,114.00,114.05,114.09,114.12$, 126.84, 126.84, 127.49, 128.55, 128.61, 128.72, 128.95, 129.01, $129.71,134.74,134.89,135.00,158.57,158.73$, 158.80, 159.71,
169.37, 172.82; HRMS calcd for $\mathrm{C}_{32} \mathrm{H}_{32} \mathrm{~N}_{2} \mathrm{O}_{4} \mathrm{Na}[\mathrm{M}+\mathrm{Na}]^{+}$: 531.2260 found: 531.2255 .

Product 5m. Pale yellow oil; ${ }^{1} \mathrm{H}$ NMR (400 $\mathrm{MHz} ; \mathrm{CDCl}_{3}$ ) $\delta \mathrm{ppm}=7.20-7.16$ (3H, m, Ph), 7.10-7.08 (2H, m, Ph), 6.88-6.85 $(1 \mathrm{H}, \mathrm{m}, \mathrm{CH}), 4.87-4.83(1 \mathrm{H}, \mathrm{m}, \mathrm{NH}), 4.27-4.13(2 \mathrm{H}, \mathrm{m}, \mathrm{CH}), 3.71$ $\left(3 \mathrm{H}, \mathrm{s}, \mathrm{CH}_{3}\right), 3.62\left(2 \mathrm{H}, \mathrm{s}, \mathrm{CH}_{2}\right), 3.15-3.10\left(2 \mathrm{H}, \mathrm{m}, \mathrm{CH}_{2}\right), 1.80-1.73$ (1H, m, CH), 1.59-1.52 (1H, m, CH), 1.40-1.47 (2H, m, $\left.\mathrm{CH}_{2}\right)$, 1.18-1.13 (4H, m, $\left.\mathrm{C}_{2} \mathrm{H}_{4}\right), 0.85-0.79\left(10 \mathrm{H}, \mathrm{m}, \mathrm{CH}_{3}+\mathrm{CH}\right) ;{ }^{13} \mathrm{C}$ NMR $\left(100 \mathrm{MHz} ; \mathrm{CDCl}_{3}\right) \delta \mathrm{ppm}=13.62,20.27,22.36,22.81$, 24.82, 32.03, 36.72, 41.11, 42.79, 45.56, 55.25, 55.91, 113.94, 126.94, 128.67, 128.68, 129.04, 129.32, 130.48, 134.83, 158.85, 171.36, 172.76; HRMS calcd for $\mathrm{C}_{26} \mathrm{H}_{36} \mathrm{~N}_{2} \mathrm{O}_{3} \mathrm{Na}[\mathrm{M}+\mathrm{Na}]^{+}$: 447.2624 found: 447.2624 .

Product 5n. Pale yellow oil; ${ }^{1} \mathrm{H}$ NMR (400 MHz; $\left.\mathrm{CDCl}_{3}\right) \delta \mathrm{ppm}$ $=8.17(1 \mathrm{H}, \mathrm{s}, \mathrm{CH}), 7.19-7.17$ (3H, m, Ph), 7.09-7.05 (4H, m, Ph), 6.74-6.74 (2H, m, Ph), 4.34-4.17 (2H, m, CH), 3.96-4.00 (1H, m, $\mathrm{NH}), 3.71\left(3 \mathrm{H}, \mathrm{m}, \mathrm{CH}_{3}\right), 3.65\left(2 \mathrm{H}, \mathrm{s}, \mathrm{CH}_{2}\right), 2.34-2.29(1 \mathrm{H}, \mathrm{m}$, $\mathrm{CH}), 1.58-1.52\left(2 \mathrm{H}, \mathrm{m}, \mathrm{CH}_{2}\right), 1.18-1.14\left(1 \mathrm{H}, \mathrm{m}, \mathrm{CH}_{2}\right)$ 1.02-1.00 $\left(6 \mathrm{H}, \mathrm{m}, \mathrm{CH}_{3}\right), 0.89-0.88\left(6 \mathrm{H}, \mathrm{m}, \mathrm{CH}_{3}\right) ;{ }^{13} \mathrm{C} \mathrm{NMR}(100 \mathrm{MHz}$; $\left.\mathrm{CDCl}_{3}\right) \delta \mathrm{ppm}=20.53,21.01,22.35,25.54,39.62,42.65,42.90$, 50.69 , 55.25, 59.49, 113.92, 126.92, 128.37, 128.77, 128.77, 128.81, 129.55, 130.94, 134.80, 158.73, 172.46, 172.76; HRMS calcd for $\mathrm{C}_{25} \mathrm{H}_{34} \mathrm{~N}_{2} \mathrm{O}_{3} \mathrm{Na}[\mathrm{M}+\mathrm{Na}]^{+}$: 433.2467 found: 475.2468 .

Product 5o. White powder; mp. $82-83{ }^{\circ} \mathrm{C} ;{ }^{1} \mathrm{H}$ NMR $(400 \mathrm{MHz}$; $\left.\mathrm{CDCl}_{3}\right) \delta \mathrm{ppm}=7.03-7.34(12 \mathrm{H}, \mathrm{m}, \mathrm{Ph}), 6.82-6.86(3 \mathrm{H}, \mathrm{m}, \mathrm{Ph}+$ $\mathrm{CH}), 5.06-5.10(1 \mathrm{H}, \mathrm{m}, \mathrm{NH}), 4.60(1 \mathrm{H}, \mathrm{s}, \mathrm{CH}), 4.23-4.27(2 \mathrm{H}, \mathrm{m}$, $\left.\mathrm{CH}_{2}\right), 3.79\left(1 \mathrm{H}, \mathrm{s}, \mathrm{CH}_{3}\right), 3.54-3.65\left(2 \mathrm{H}, \mathrm{m}, \mathrm{CH}_{2}\right), 1.86-1.93(1 \mathrm{H}$, $\mathrm{m}, \mathrm{CH}), 1.43-1.47\left(2 \mathrm{H}, \mathrm{m}, \mathrm{CH}_{2}\right), 0.82-0.91\left(6 \mathrm{H}, \mathrm{m}, 2 \times \mathrm{CH}_{3}\right) ;{ }^{13} \mathrm{C}$ NMR (100 MHz; $\left.\mathrm{CDCl}_{3}\right) \delta \mathrm{ppm}=21.73,22.37,22.82,23.10$, 24.56, 25.17, 37.10, 40.78, 41.26, 41.62, 42.54, 42.84, 48.55, $55.28,56.35,73.03,114.05,126.02,126.98,127.39,128.66$, 128.79, 128.84, 128.98, 129.01, 130.31, 134.52, 137.55, 158.91, 170.45, 173.44; HRMS calcd for $\mathrm{C}_{29} \mathrm{H}_{34} \mathrm{~N}_{2} \mathrm{O}_{3} \mathrm{Na}[\mathrm{M}+\mathrm{Na}]^{+}$: 481.2467 found: 481.2467 .

Product 5p. Pale yellow oil; ${ }^{1} \mathrm{H}$ NMR $\left(400 \mathrm{MHz} ; \mathrm{CDCl}_{3}\right) \delta \mathrm{ppm}$ $=7.15(5 \mathrm{H}, \mathrm{m}, \mathrm{Ph}), 6.72-7.03(5 \mathrm{H}, \mathrm{m}, \mathrm{Ph}+\mathrm{CH}), 4.74-5.00(1 \mathrm{H}$, $\mathrm{m}, \mathrm{NH}), 4.04-4.32\left(2 \mathrm{H}, \mathrm{m}, \mathrm{CH}_{2}\right), 3.71\left(3 \mathrm{H}, \mathrm{m}, \mathrm{CH}_{3}\right), 3.55-3.65$ $\left(2 \mathrm{H}, \mathrm{m}, \mathrm{CH}_{2}\right), 2.95-3.26\left(2 \mathrm{H}, \mathrm{m}, \mathrm{CH}_{2}\right), 1.06-1.89(12 \mathrm{H}, \mathrm{m}$, $\left.\mathrm{C}_{10} \mathrm{H}_{10}, \mathrm{CH}_{2}\right), 0.81\left(9 \mathrm{H}, \mathrm{m}, \mathrm{CH}_{3}\right) ;{ }^{13} \mathrm{C} \mathrm{NMR}\left(100 \mathrm{MHz} ; \mathrm{CDCl}_{3}\right.$ ) $\delta \mathrm{ppm}=13.85,22.28,22.45,22.73,24.73,26.66,29.88,31.20$, $36.67,41.02,42.69,45.73,55.14,55.77$; HRMS calcd for $\mathrm{C}_{32} \mathrm{H}_{32} \mathrm{~N}_{2} \mathrm{O}_{4} \mathrm{Na}[\mathrm{M}+\mathrm{Na}]^{+}: 475.2934$ found: 475.2937 .

Product 5t. White powder; mp. $104-105{ }^{\circ} \mathrm{C}$; ${ }^{1} \mathrm{H}$ NMR (400 $\left.\mathrm{MHz} ; \mathrm{CDCl}_{3}\right) \delta \mathrm{ppm}=6.82-7.30(15 \mathrm{H}, \mathrm{m}, \mathrm{Ph}+\mathrm{CH}), 5.02-4.99$ $(1 \mathrm{H}, \mathrm{m}, \mathrm{NH}), 4.52\left(2 \mathrm{H}, \mathrm{s}, \mathrm{CH}_{2}\right), 4.30-4.35\left(2 \mathrm{H}, \mathrm{m}, \mathrm{CH}_{2}\right), 3.80$ $\left(3 \mathrm{H}, \mathrm{s}, \mathrm{CH}_{3}\right), 3.61-3.63\left(2 \mathrm{H}, \mathrm{m}, \mathrm{CH}_{2}\right), 1.87-1.91(1 \mathrm{H}, \mathrm{m}, \mathrm{CH})$, 1.45-1.49 (2H, m, $\left.\mathrm{CH}_{2}\right), 0.82-0.86\left(6 \mathrm{H}, \mathrm{m}, 2 \times \mathrm{CH}_{3}\right) ;{ }^{13} \mathrm{C} \mathrm{NMR}$ $\left(100 \mathrm{MHz} ; \mathrm{CDCl}_{3}\right) \delta \mathrm{ppm}=22.42,22.75,25.17,43.37,55.30$, 114.25, 127.32, 127.69, 128.63, 128.67, 145.51, 158.95, 170.66; HRMS calcd for $\mathrm{C}_{29} \mathrm{H}_{34} \mathrm{~N}_{2} \mathrm{O}_{3} \mathrm{Na}[\mathrm{M}+\mathrm{Na}]^{+}: 481.2467$ found: 481.2455 .

Product 5u. Pale yellow oil; ${ }^{1} \mathrm{H}$ NMR $\left(400 \mathrm{MHz} ; \mathrm{CDCl}_{3}\right) \delta \mathrm{ppm}$ $=7.22-7.19(4 \mathrm{H}, \mathrm{m}, \mathrm{Ph}), 7.09-7.01(3 \mathrm{H}, \mathrm{m}, \mathrm{Ph}), 6.82-6.80(2 \mathrm{H}$, m, Ph), 6.35 (1H, s, CH), $4.91(1 \mathrm{H}, \mathrm{s} \mathrm{br}, \mathrm{NH}), 4.45\left(2 \mathrm{H}, \mathrm{s}, \mathrm{CH}_{2}\right)$, $3.74\left(3 \mathrm{H}, \mathrm{s}, \mathrm{CH}_{3}\right), 3.58-3.56\left(2 \mathrm{H}, \mathrm{m}, \mathrm{CH}_{2}\right), 3.08-3.06(2 \mathrm{H}, \mathrm{m}$, $\mathrm{CH}_{2}$ ), 1.80-1.76 (1H, m, CH), 1.34-1.22 (6H, m, $\left.\mathrm{C}_{3} \mathrm{H}_{6}\right), 0.85-0.74$ $\left(9 \mathrm{H}, \mathrm{m}, 3 \times \mathrm{CH}_{3}\right) ;{ }^{13} \mathrm{C} \mathrm{NMR}\left(100 \mathrm{MHz} ; \mathrm{CDCl}_{3}\right) \delta \mathrm{ppm}=13.72$, 
$20.03,22.38,22.77,25.15,31.50,36.96,39.01,41.34,48.09$, $55.30,114.23,127.00,127.24,128.66,128.76,129.41,134.62$, 158.93, 170.61, 173.42; HRMS calcd for $\mathrm{C}_{26} \mathrm{H}_{36} \mathrm{~N}_{2} \mathrm{O}_{3} \mathrm{Na}[\mathrm{M}+$ $\mathrm{Na}]^{+}: 447.2624$ found: 447.2611 .

Product 5v. Pale yellow oil; ${ }^{1} \mathrm{H}$ NMR $\left(400 \mathrm{MHz} ; \mathrm{CDCl}_{3}\right) \delta \mathrm{ppm}$ $=7.27-7.15(4 \mathrm{H}, \mathrm{m}, \mathrm{Ph}), 7.08-7.01(3 \mathrm{H}, \mathrm{m}, \mathrm{Ph}), 7.05-7.03(2 \mathrm{H}$, $\mathrm{m}, \mathrm{Ph}), 6.82(2 \mathrm{H}, \mathrm{m}, \mathrm{Ph}), 6.37$ (1H, s, CH), $4.91(1 \mathrm{H}, \mathrm{s}$ br, NH), $4.45\left(2 \mathrm{H}, \mathrm{s}, \mathrm{CH}_{2}\right), 3.74\left(3 \mathrm{H}, \mathrm{s}, \mathrm{CH}_{3}\right), 3.61-3.52\left(2 \mathrm{H}, \mathrm{m}, \mathrm{CH}_{2}\right)$, 3.09-3.02 (2H, m, $\left.\mathrm{CH}_{2}\right), 1.80-1.76(1 \mathrm{H}, \mathrm{m}, \mathrm{CH}), 1.36-1.33(4 \mathrm{H}$, $\left.\mathrm{m}, 2 \times \mathrm{CH}_{2}\right), 1.19\left(6 \mathrm{H}, \mathrm{m}, 2 \times \mathrm{CH}_{2}\right), 0.81-0.74\left(9 \mathrm{H}, \mathrm{m}, 3 \times \mathrm{CH}_{3}\right)$; ${ }^{13} \mathrm{C}$ NMR $\left(100 \mathrm{MHz} ; \mathrm{CDCl}_{3}\right) \delta \mathrm{ppm}=13.97,22.36,22.51,22.76$, 25.14, 26.14, 26.53, 29.39, 31.41, 36.97, 39.31, 41.32, 48.07, $55.28,56.46,14.21,126.98,127.23,128.75,129.41,134.62$, 158.92, 170.57, 173.40; HRMS calcd for $\mathrm{C}_{28} \mathrm{H}_{40} \mathrm{~N}_{2} \mathrm{O}_{3} \mathrm{Na}[\mathrm{M}+$ $\mathrm{Na}]^{+}: 475.2937$ found: 475.2938 .

Product 5w. Pale yellow oil; ${ }^{1} \mathrm{H}$ NMR $\left(400 \mathrm{MHz} ; \mathrm{CDCl}_{3}\right) \delta \mathrm{ppm}$ $=7.24-7.15(4 \mathrm{H}, \mathrm{m}, \mathrm{Ph}), 7.11-7.10(2 \mathrm{H}, \mathrm{m}, \mathrm{Ph}), 7.05-7.03(2 \mathrm{H}$, $\mathrm{m}, \mathrm{Ph}), 6.86(1 \mathrm{H}, \mathrm{s}, \mathrm{CH}), 6.81-6.79\left(2 \mathrm{H}, \mathrm{m}, \mathrm{CH}_{2}\right), 5.00-4.97$ $(1 \mathrm{H}, \mathrm{s}$ br, $\mathrm{NH}), 4.46\left(2 \mathrm{H}, \mathrm{s}, \mathrm{CH}_{2}\right), 4.15-4.10\left(2 \mathrm{H}, \mathrm{s}, \mathrm{CH}_{2}\right), 3.83-$ $3.80\left(2 \mathrm{H}, \mathrm{m}, \mathrm{CH}_{2}\right), 3.73\left(3 \mathrm{H}, \mathrm{s}, \mathrm{CH}_{3}\right), 3.62\left(2 \mathrm{H}, \mathrm{m}, \mathrm{CH}_{2}\right), 1.82-$ $1.78(1 \mathrm{H}, \mathrm{m}, \mathrm{CH}), 1.43-1.36\left(2 \mathrm{H}, \mathrm{m}, \mathrm{CH}_{2}\right), 1.22-1.18(3 \mathrm{H}, \mathrm{m}$, $\mathrm{CH}_{3}$ ), 0.79-0.75 (6H, m, $\left.2 \times \mathrm{CH}_{3}\right) ;{ }^{13} \mathrm{C} \mathrm{NMR} \mathrm{(100} \mathrm{MHz;} \mathrm{CDCl}_{3}$ ) $\delta \mathrm{ppm}=14.13,22.34,22.73,25.09,36.84,41.10,41.24,48.32$, 55.28, 56.22, 61.28; HRMS calcd for $\mathrm{C}_{26} \mathrm{H}_{34} \mathrm{~N}_{2} \mathrm{O}_{5} \mathrm{Na}[\mathrm{M}+\mathrm{Na}]^{+}$: 477.2365 found: 477.2362 .

Product 5x. Pale yellow oil; ${ }^{1} \mathrm{H}$ NMR $\left(400 \mathrm{MHz} ; \mathrm{CDCl}_{3}\right) \delta \mathrm{ppm}$ $=7.19-7.14(4 \mathrm{H}, \mathrm{m}, \mathrm{Ph}), 7.04-6.96(5 \mathrm{H}, \mathrm{m}, \mathrm{Ph}), 6.83-6.81(1 \mathrm{H}$, $\mathrm{m}, \mathrm{CH}), 6.74-6.72$ (2H, m, Ph), 6.37-6.33 (2H, m, Ph), 5.00-4.96 $(1 \mathrm{H}, \mathrm{s}$ br, NH$), 4.42\left(2 \mathrm{H}, \mathrm{s}, \mathrm{CH}_{2}\right), 4.22-4.20\left(2 \mathrm{H}, \mathrm{m}, \mathrm{CH}_{2}\right), 3.74-$ $3.69\left(9 \mathrm{H}, \mathrm{m}, 3 \times \mathrm{CH}_{3}\right), 3.51-3.50\left(2 \mathrm{H}, \mathrm{m}, \mathrm{CH}_{2}\right), 1.76-1.72(1 \mathrm{H}$, $\mathrm{m}, \mathrm{CH}), 1.39-1.35\left(2 \mathrm{H}, \mathrm{m}, \mathrm{CH}_{2}\right), 0.77-0.73\left(6 \mathrm{H}, \mathrm{m}, 2 \times \mathrm{CH}_{3}\right) ;{ }^{13} \mathrm{C}$ NMR $\left(100 \mathrm{MHz} ; \mathrm{CDCl}_{3}\right) \delta \mathrm{ppm}=22.49,22.73,25.05,37.02$, 38.89, 41.26, 47.84, 55.24, 55.27, 55.39, 98.52, 103.83, 114.17, 118.69, 126.84, 127.14, 128.59, 128.76, 129.53, 130.34, 134.69, 158.64, 158.76, 160.45, 170.24, 173.24; HRMS calcd for $\mathrm{C}_{31} \mathrm{H}_{38} \mathrm{~N}_{2} \mathrm{O}_{5} \mathrm{Na}[\mathrm{M}+\mathrm{Na}]^{+}: 541.2678$ found: 541.2671 .

Product 5y. Pale yellow oil; ${ }^{1} \mathrm{H}$ NMR $\left(400 \mathrm{MHz} ; \mathrm{CDCl}_{3}\right) \delta \mathrm{ppm}$ $=7.29-7.09(5 \mathrm{H}, \mathrm{m}, \mathrm{Ph}), 7.04-7.02(2 \mathrm{H}, \mathrm{m}, \mathrm{Ph}), 6.82-6.77(2 \mathrm{H}$, $\mathrm{m}, \mathrm{Ph}), 6.18(1 \mathrm{H}, \mathrm{s}, \mathrm{CH}), 4.87-4.83(1 \mathrm{H}, \mathrm{s}$ br, NH$), 4.44-4.43(2 \mathrm{H}$, $\left.\mathrm{m}, \mathrm{CH}_{2}\right), 3.73\left(3 \mathrm{H}, \mathrm{s}, \mathrm{CH}_{3}\right), 3.57-3.56\left(2 \mathrm{H}, \mathrm{m}, \mathrm{CH}_{2}\right), 1.78-1.69$ (1H, m, CH), 1.38-1.17 (10H, m, $\left.3 \times \mathrm{CH}_{3}+\mathrm{CH}\right), 0.87-0.74(8 \mathrm{H}$, $\left.\mathrm{m}, 2 \times \mathrm{CH}_{3}+\mathrm{CH}_{2}\right) ;{ }^{13} \mathrm{C} \mathrm{NMR}\left(100 \mathrm{MHz} ; \mathrm{CDCl}_{3}\right) \delta \mathrm{ppm}=22.41$, 22.75 , 25.19, 28.56, 36.90, 41.42, 47.75, 51.00, 55.30, 56.84, 114.20, 126.97, 127.22, 128.61, 128.66, 129.57, 134.68, 158.89, 169.74, 173.25; HRMS calcd for $\mathrm{C}_{26} \mathrm{H}_{36} \mathrm{~N}_{2} \mathrm{O}_{3} \mathrm{Na}[\mathrm{M}+\mathrm{Na}]^{+}$: 447.2624 found: 447.2614 .

Product 5z. White powder; mp. 94-95 ${ }^{\circ} \mathrm{C} ;{ }^{1} \mathrm{H}$ NMR $(400$ $\left.\mathrm{MHz} ; \mathrm{CDCl}_{3}\right) \delta \mathrm{ppm}=6.84-7.33(9 \mathrm{H}, \mathrm{m}, \mathrm{Ph}), 6.35(1 \mathrm{H}, \mathrm{m}$, $\mathrm{CH}), 4.94-4.97$ (1H, m, NH), 4.50-4.51 (2H, m, $\left.\mathrm{CH}_{2}\right), 3.78$ $\left(3 \mathrm{H}, \mathrm{s}, \mathrm{CH}_{3}\right), 3.57-3.62\left(2 \mathrm{H}, \mathrm{m}, \mathrm{CH}_{2}\right), 0.79-1.82(20 \mathrm{H}, \mathrm{m}$, $\left.\mathrm{C}_{6} \mathrm{H}_{11}+\mathrm{C}_{4} \mathrm{H}_{9}\right) ;{ }^{13} \mathrm{C} \mathrm{NMR}\left(100 \mathrm{MHz} ; \mathrm{CDCl}_{3}\right) \delta \mathrm{ppm}=22.43$, 22.74, 24.69, 25.18, 25.30, 32.70, 32.84, 37.01, 41.40, 47.95, 48.15 , 55.28, 56.52, 114.20, 126.96, 127.23, 128.65, 128.71, 129.24, 129.48, 129.89, 134.65, 158.92, 169.61, 173.28; HRMS calcd for $\mathrm{C}_{28} \mathrm{H}_{38} \mathrm{~N}_{2} \mathrm{O}_{3} \mathrm{Na}[\mathrm{M}+\mathrm{Na}]^{+}: 473.2780$ found: 473.2770.

\section{Acknowledgements}

We gratefully acknowledge the financial support of NCN project Harmonia No. 2014/14/M/ST5/00030 for financial assistance. This work is dedicated to prof. Sławomir Jarosz on the occasion of his $65^{\text {th }}$ birthday.

\section{Notes and references}

1 K. Atul, K. G. Maneesh, K. Mukesh and S. Deepti, RSC Adv., 2013, 3, 1673.

2 M. O. Simon and C. J. Li, Chem. Soc. Rev., 2012, 41, 1415; U. M. Lindstrom, Chem. Rev., 2002, 102, 2751; O. V. Ershov, M. Y. Ievlev, V. A. Tafeenko and O. E. Nasakin, Green Chem., 2015, 17, 4234; C. Tao, H. Leqin, B. Li, H. Haiyan and G. Xiaorui, RSC Adv., 2014, 4, 727.

3 K. Atul, K. G. Maneesh and K. Mukesh, Tetrahedron Lett., 2011, 52, 4521; D. G. Blackmond, A. Armstrong, V. Coombie and A. Wells, Angew. Chem., Int. Ed., 2007, 46, 3798.

4 T. Dwars, E. Paetzold and G. Oehme, Angew. Chem., Int. Ed., 2005, 44, 7174; P. Walde, H. Umakoshi, P. Stano and F. Mavelli, Chem. Commun., 2014, 50, 10177; P. Walde, Origins Life Evol. Biospheres, 2006, 36, 109.

5 F. Szoka and D. Papahadjopoulos, Annu. Rev. Biophys. Bioeng., 1980, 9, 467; T. Kunitake, Y. Okahata, K. Tamaki, F. Kumamaru and M. Takayanagi, Chem. Lett., 1977, 6, 387; E. Feitosa, P. C. A. Barreleiro and G. Olofsson, Chem. Phys. Lipids, 2000, 105, 201; R. O. Brito and E. F. Marques, Chem. Phys. Lipids, 2005, 137, 18.

6 M. Antonietti and S. Förster, Adv. Mater., 2003, 15, 1323.

7 J. H. Fendler, Membrane Mimetic Chemistry, John Wiley\&Sons, New York, 1982.

8 T. M. Allen, Trends Pharmacol. Sci., 1994, 15, 215; G. Gregoriadis, Trends Biotechnol., 1995, 13, 527; Y. Barenholz, Curr. Opin. Colloid Interface Sci., 2001, 6, 66; V. P. Torchilin, Nat. Rev. Drug Discovery, 2005, 4, 145; F. Meng, Z. Zhong and J. Feijen, Biomacromolecules, 2009, 10, 197; R. R. Sawant and V. P. Torchilin, Soft Matter, 2010, 6, 4026; P. Tanner, P. Baumann, R. Enea, O. Onaca, C. Palivan and W. Meier, Acc. Chem. Res., 2011, 44, 1039.

9 F. M. Menger, J. U. Rhee and H. K. Rhee, J. Org. Chem., 1975, 40, 3803; M. S. Goedheijt, B. E. Hanson, J. N. H. Reek, P. C. J. Kamer and P. W. N. M. van Leeuwen, J. Am. Chem. Soc., 2000, 122, 1650; J. B. F. N. Engberts and M. J. Blandamer, Chem. Commun., 2001, 18, 1701; S. Balakumar, P. Thanasekaran, E. Rajkumar, K. J. Adikalasamy, S. Rajagopal, R. Ramaraj, T. Rajendran, B. Manimaran and K. L. Lu, Org. Biomol. Chem., 2006, 4, 352; G. La Sorella, G. Strukul and A. Scarso, Green Chem., 2015, 17, 644.

10 T. Kunitake, Y. Okahata, R. Ando, S. Shinkai and S. Hirakawa, J. Am. Chem. Soc., 1980, 102, 7877; M. V. Scarpa, P. S. Araujo, S. Schreier, A. Sesso, A. G. Oliveira, H. Chaimovich and I. M. Cuccovia, Langmuir, 2000, 16, 993; J. Perez-Juste, F. Hollfelder, A. J. Kirby and J. B. F. N. Engberts, Org. Lett., 2000, 2, 127. 
11 U. Costantino, F. Feringuelli, M. Orru, M. Nocchetti, O. Piermati and F. Pizzo, Eur. J. Org. Chem., 2009, 1214.

12 M. Ghandi, M. T. Nazeri and M. Kubicki, Tetrahedron, 2013, 69, 4979.

13 S. Handa, Y. Wang, F. Gallou and B. H. Lipshutz, Science, 2015, 349, 1087; S. Handa, E. D. Slack and B. H. Lipshutz, Angew. Chem., Int. Ed., 2015, 54, 11994.

14 P. Klumphu and B. H. Lipshutz, J. Org. Chem., 2014, 79, 888.

15 J. C. Fennewald and B. H. Lipshutz, Green Chem., 2014, 16, 1097; F. Yang, P. Klumphu, Y. M. Liang and B. H. Lipshutz, Chem. Commun., 2014, 16, 1097.

16 A. Bhattacharjya, P. Klumphu and B. H. Lipshutz, Org. Lett., 2015, 17, 1122; J. C. Fennewald, E. B. Landstrom and B. H. Lipshutz, Tetrahedron Lett., 2015, 56, 3608.

17 G. Lu and C. Cai, Catal. Commun., 2010, 11, 745; A. Kumar, M. K. Gupta, M. Kumar and D. Saxena, RSC Adv., 2013, 3, 1673.

18 C. S. McKay, D. C. Kennedy and J. P. Pezacki, Tetrahedron Lett., 2009, 50, 1893.

19 A. Kumar, M. K. Gupta and M. Kumar, Tetrahedron Lett., 2010, 51, 1582.

20 D. Paprocki, D. Koszelewski, P. Walde and R. Ostaszewski, $R S C$ Adv., 2015, 5, 102828; D. Paprocki, D. Koszelewski, A. Żądło, P. Walde and R. Ostaszewski, RSC Adv., 2016, 6, 68231.

21 E. Vessally, A. Ramazani and E. Yaaghubi, Monatsh. Chem., 2011, 142, 1143; J. Taran, A. Ramazani, S. W. Joo, K. Slepokura and T. Lis, Helv. Chim. Acta, 2014, 97, 1088.

22 M. O. Simon and C. J. Li, Chem. Soc. Rev., 2012, 41, 1427.

23 C. Kalinski, M. Umkehrer, L. Weber, J. Kolb, C. Burdack and G. Ross, Mol. Diversity, 2010, 14, 513; A. Domling, Chem. Rev., 2006, 106, 17; D. L. Boger, J. Desharnais and K. Capps, Angew. Chem., Int. Ed., 2003, 42, 4138; J. Zhu, Eur. J. Org. Chem., 2003, 1133; R. V. A. Orru and M. de Greef, Synthesis, 2003, 1471; A. Domling and I. Ugi, Angew. Chem., Int. Ed., 2000, 39, 3168; L. Weber, K. Illgen and M. Almstetter, Synlett, 1999, 366.

24 K. Rossen, P. J. Pye, L. M. DiMichele, R. P. Volante and P. J. Reider, Tetrahedron Lett., 1998, 39, 6823.
25 I. Ugi, R. Meyr, U. Fetzer and C. Steinbrückner, Angew. Chem., 1959, 71, 386.

26 G. Neyer, J. Achatz, B. Danzer and I. Ugi, Heterocycles, 1990, 30, 863.

27 A. Domling and I. Ugi, Angew. Chem., Int. Ed., 2000, 39, 3168. 28 M. C. Pirrung and K. Das Sarma, J. Am. Chem. Soc., 2003, 126, 444.

29 M. A. Mirono, M. N. Ivantsova and V. S. Mokrushi, Mol. Diversity, 2003, 6, 193.

30 T. Kunitake and Y. Okahata, J. Am. Chem. Soc., 1977, 99, 3860; Y. Kondo, M. Abe, K. Ogino, H. Uchiyama, E. D. Tucker, J. F. Scamehorn and S. D. Christian, Colloids Surf., B, 1993, 1, 51-56; F. Caboi and M. Monduzzi, Langmuir, 1996, 12, 3548; R. McNeil and J. K. Thomas, J. Colloid Interface Sci., 1980, 73, 522.

31 E. W. Kaler, A. K. Murthy, B. E. Rodriguez and J. A. N. Zasadzinski, Science, 1989, 245, 1371; D. D. Lasic, P. Joannic, B. C. Keller, P. M. Frederik and L. Auvray, Adv. Colloid Interface Sci., 2001, 89-90, 337; K. Horbaschek, H. Hoffmann and J. Hao, J. Phys. Chem. B, 2000, 104, 2781; V. Guida, Adv. Colloid Interface Sci., 2010, 161, 77.

32 I. Johnson and M. T. Z. Spence, in The Molecular Probes Handbook-A Guide to Fluorescent Probes and Labeling, Life Technologies Corporation, 11th edn, 2010, pp. 530-533.

33 L. M. Loew, in Spectroscopic Membrane Probes, CRC Press, 1988, pp. 193-220.

34 R. D. Klauner and D. E. Wolf, Biochemistry, 1980, 19, 6199.

35 C. H. Thomas and P. L. Luisi, J. Phys. Chem. B, 2004, 108, 11290.

36 Z. Zhang, W. Huang, J. Tang, E. Wang and S. Dong, Biophys. Chem., 2002, 97, 7.

37 V. Patel, B. Bharatiya, D. Ray, V. K. Aswal and P. Bahadur, J. Colloid Interface Sci., 2015, 441, 106.

38 K. Meguellat, A. Fallah-Araqhi, J. C. Baret, A. El Harrak, T. Mangeat, C. M. Marques, A. D. Griffiths and S. Ladame, Chem. Commun., 2013, 49, 11332.

39 H. G. O. Alvim, E. N. da Silva and B. A. D. Neto, RSC Adv., 2014, 4, 54282 . 